\title{
A Midsummer Light's Dream: The Journey of Designing the Lighting For a Classic Tale
}

\author{
Tim Thistleton
}

Follow this and additional works at: https://researchrepository.wvu.edu/etd

\section{Recommended Citation}

Thistleton, Tim, "A Midsummer Light's Dream: The Journey of Designing the Lighting For a Classic Tale" (2015). Graduate Theses, Dissertations, and Problem Reports. 6791.

https://researchrepository.wvu.edu/etd/6791

This Thesis is protected by copyright and/or related rights. It has been brought to you by the The Research Repository @ WVU with permission from the rights-holder(s). You are free to use this Thesis in any way that is permitted by the copyright and related rights legislation that applies to your use. For other uses you must obtain permission from the rights-holder(s) directly, unless additional rights are indicated by a Creative Commons license in the record and/ or on the work itself. This Thesis has been accepted for inclusion in WVU Graduate Theses, Dissertations, and Problem Reports collection by an authorized administrator of The Research Repository @ WVU. For more information, please contact researchrepository@mail.wvu.edu. 


\title{
A Midsummer Light's Dream:
}

The Journey of Designing the Lighting For a Classic Tale

\author{
By: \\ Tim Thistleton
}

Thesis submitted to the College of Creative Arts at West Virginia University

in partial fulfillment of the requirements

for the degree of

Master of Fine Arts

in

Theatre

\section{Committee Members:}

Joshua Blackmer Williamson (chair), Director/ Associate Professor of Theatre Alan McEwen, Clinical Assistant Professor of Lighting \& Sound Design Jerry McGonigle, Director, Graduate Acting/ Professor of Acting and Directing

School of Theatre and Dance

Morgantown, WV 2015

Keywords: A Midsummer Night's Dream; Lighting Design; Theatre; Gladys G. Davis Theatre; CAC; Theater; Shakespeare; Stage Lighting 


\section{ABSTRACT \\ Lighting Design for A Midsummer Night's Dream \\ Tim Thistleton}

This document is a discussion of the process involved with creating and executing a lighting design for A Midsummer Night's Dream, by William Shakespeare. It will follow my journey as the designer from first read, through the evolution of the design, and finally opening night. This paper will show my process as a designer through examples of my research, paperwork, and stories of collaboration. It will conclude with an evaluation of my work. 


\section{$\underline{\text { Table of Contents }}$}

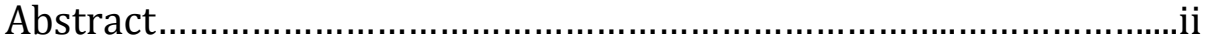

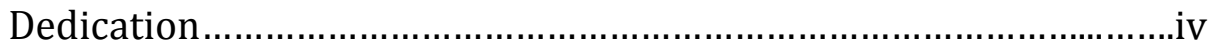

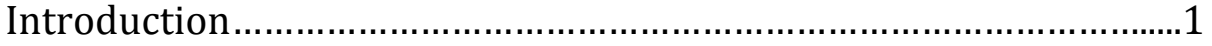

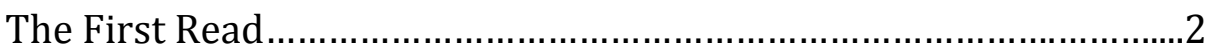

The Design Concept and First Meeting .........................................6

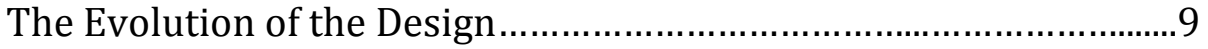

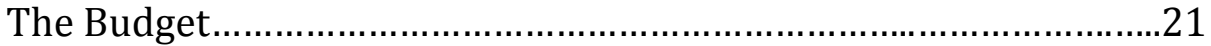

Technical Rehearsals: Cutting Your Losses....................................25

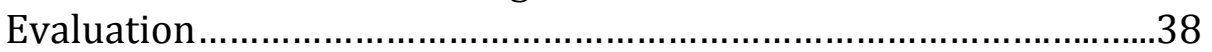

Conclusion...............................................................................4 40

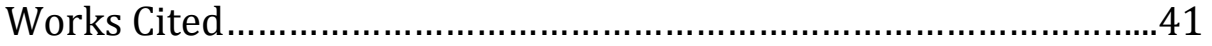

Appendix A- Channel Hookup.......................................................43

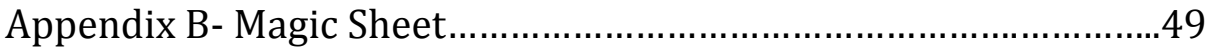

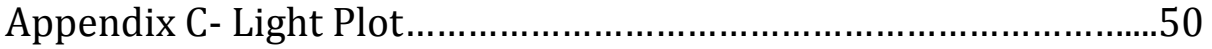

Appendix D- Cue Synopsis...........................................................51

Appendix E- Gladys G. Davis Theatre Lighting Inventory................53

Appendix F-Additional Research Images.......................................54

Appendix G- Additional Production Photos....................................56

Figure 1- Costume Research..................................................

Figure 2- Watercolor by P. Marcius-Simons....................................6

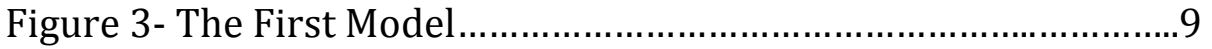

Figure 4- The Second Model......................................................10

Figure 5- The Third Model........................................................12

Figure 6- Forest Research.......................................................13

Figure 7- Forest Research.........................................................14

Figure 8- Atmosphere Research...............................................14

Figure 9- Texture Research .................................................... 15

Figure 10- Sunset Research.....................................................16

Figure 11- Lighting Key...........................................................19

Figure 12- Acting Area Layout................................................20

Figure 13- Altman 6' Ministrip.................................................22

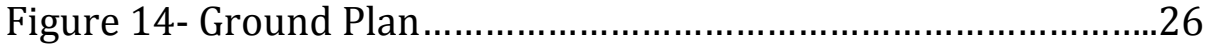

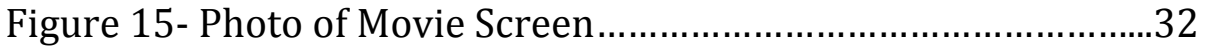

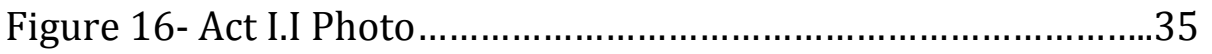

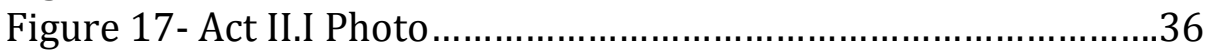

Figure 18- Act II.II Photo........................................................... 36

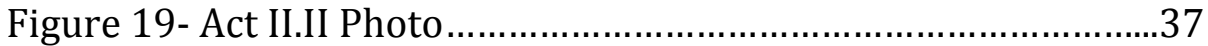

Figure 20- Act III.II Photo......................................................... 37 


\section{Dedication}

The writing of this document would not have been possible without the help and guidance of my committee. To them, I am eternally grateful. I would also like

to dedicate this to my family and loved ones, who have always been supportive, no matter what the endeavor. 


\section{$\underline{\text { Introduction }}$}

During the spring of 2014, I was tasked to be the lighting designer for West Virginia University's production of A Midsummer Night's Dream, by William Shakespeare. The show was directed by Professor Jerry McGonigle, with costumes designed by Professor Mary McClung, Scene Design by fellow graduate student Jake Bigelow, sound design by Professor Alan McEwen, and technical direction by Professor Steven Neuenschwander. The play would be performed in the Gladys G. Davis Theatre, a thrust theatre in the Creative Arts Center at WVU. The play opened in November, 2014.

I took a trip that spring to Washington, D.C. As I was walking around to see the usual sights, I stumbled upon the Folger Shakespeare Library. The library was celebrating Shakespeare's $450^{\text {th }}$ birthday with a great display of "Shakespeare Through The Years." There was a glass case with a copy of Midsummer, and next to it, an ipad. On the ipad was a scanned version of A Midsummer Night's Dream where each page had a different watercolor painting done over the text. Every page of the book had become a new piece of art. The watercolor paintings had been done by Pickney Marcius-Simons in 1908, and they had given me the jumping off point that I was very much in search for. 


\section{The First Reading}

I remembered being assigned a costume project when I was a student at SUNY Fredonia that centered on A Midsummer Night's Dream, but I didn't remember reading it. I had never seen the show before either, so I entered my first reading with an open mind and a blank canvas other than what I had seen on display at the Folger Library, in Washington D.C. The library was full of original documents, but what caught my eye was a French edition of A Midsummer Night's Dream from 1908, more on that later.

The show takes place in Athens, just after Duke Theseus has defeated the Amazonians and taken their queen as his bride to be. The first scene takes place at the engagement party at the Palace of Athens. At the time of my first reading, our costumer designer, Professor McClung, had already sent me some initial research

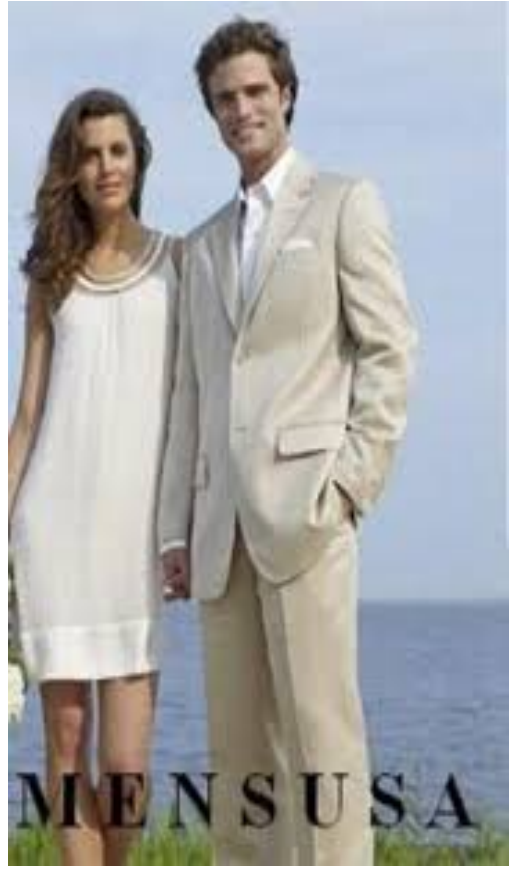

photos. The photos were specifically for the first scene, which did not have a particular time of day as far as the text was concerned. This would give me the opportunity to be more flexible with my design choices. It would allow me, as the designer, to decide the time of day and convey it with the lights.

Professor McClung's photo said one thing to me:

Hamptons summer cocktail party. I decided that I would use this chance to design a somewhat

(Figure 1: costume research by Professor Mary McClung) 
unrealistic sunset for the first scene. A Midsummer Night's Dream is a "magical" tale, and I wanted to start the show with a look that could occur in the real world but still have that "magical" sense to it. I wanted it to set the tone for the rest of the play, I think going too realistic with the first scene would have created too much juxtaposition between the scenes.

I am a firm believer that the first read should just be about getting an idea for the flow of the story and the themes that are in play, so I stopped at that and decided to just read the play and not think too much about the lighting design until I had a chance to digest the play and revisit the script later.

During the first scene we are introduced to the four lovers. Hermia has been betrothed to Demetrius by her father, Egeus. Hermia's true love is Lysander who is the Romeo to Demetrius' Paris. Lysander has a touch of that bad-boy edge, so just picture Baz Luhrmann's telling of Romeo and Juliet. The last piece of the puzzle is Helena; Helena is painfully in love with Demetrius, who wants absolutely nothing to do with her. Hermia has been ordered to marry Demtrius, which she refuses. Under the law of Athens, she is given two choices: she can become a nun for the rest of her life, or she can hang. She is given four days to mull over the decision. Lysander, knowing Hermia's fate, proposes to Hermia and the two plan their escape to a cabin on the other side of a forest where they will be able to live the rest of their days together.

The next scene introduces what I think is the third plotline of the play. A group of handymen have gotten together to start producing a play to be performed at Theseus' Wedding. We meet the characters that will serve as the comic relief 
throughout the play and it is decided that this group too will adjourn to the woods for their rehearsal because it will give them the necessary privacy.

Finally, we are in the forest. This is the place that will serve as the setting for the majority of the play. We meet Oberon and Titania, the king and queen of the faeries. We also meet Puck, Oberon's mischievous, yet loyal, servant who will play a large role in the progression of the play. Lysander and Hermia arrive in the heart of the forest followed by Demetrius who has been followed by Helena. As part of Oberon's master plan to win an Indian boy from Titania, he has sent Puck to cast a spell on Titania that causes her to fall in love with the next thing she sees. He also asks Puck to cast the same spell on an Athenian that he has seen in the forest, hoping that it will cause Demetrius to fall in love with Helena and solve everyone's problems. Puck confuses Lysander for Demetrius. Lysander falls in love with Helena, and promptly leaves Hermia in the middle of nowhere. Titania wakes up to the sound of Nick Bottom, one of craftsmen that has been rehearsing the play. However, Puck has recently given him the head of a donkey, for an extra level of humiliation. After a good amount of arguing and running away from each other, the four lovers are finally corralled by Puck, who fixes his mistake and makes it so that Demetrius is in love with Helena and Lysander once again loves Hermia.

Oberon, having already taken what he wanted from Titania, releases her from the spell. The two leave the mortals sleeping in the forest so that they may wake and feel the affects of the tinkering that Puck has done. The four lovers are found by a hunting party that is being led by Theseus. It is the morning of the day which Hermia must decide if she wants to die or be a nun. Since Demetrius is now 
in love with Helena, Theseus decides that he will allow Hermia to marry Lysander and invites the two couples to be wed in the ceremony alongside he and Hippolyta. Back in Athens, the craftsmen are mourning the loss of their friend, Nick Bottom, who is now a donkey. Bottom is nowhere to be found. Much to their surprise, Bottom not only enters in his original human form, but also informs them that their play has been chosen and they will be performing it at the wedding.

The play is performed to the best of the player's ability, which is to say it was awful but it had a lot of heart. The court takes pleasure in how bad the performance is and after the final scene of the play within a play, the clock strikes midnight, and everyone retires to bed. Oberon, Titania and Puck do a little wrapping up of their own, with Oberon making sure that the faeries bless the master bed to ensure the health of the babies that come of it. In the final moments, Puck addresses the audience. He asks the audience to pretend that this has all been a dream if they were dissatisfied with what they have just seen. He requests their applause, and promises that he will make amends if need be.

Overall, I remember enjoying the play. It was a quick read, and the story flowed well. My lighting cues would need to flow in a similar nature. 


\section{The Design Concept and First Meeting}

As I mentioned earlier, my trip to the Folger Shakespeare Library would prove to be the jumping off point for my design conceptually. At the time of my visit, I had not yet read the play, so it was admittedly early to be choosing a design concept, but I felt good about where I was headed and I thought I owed it to myself

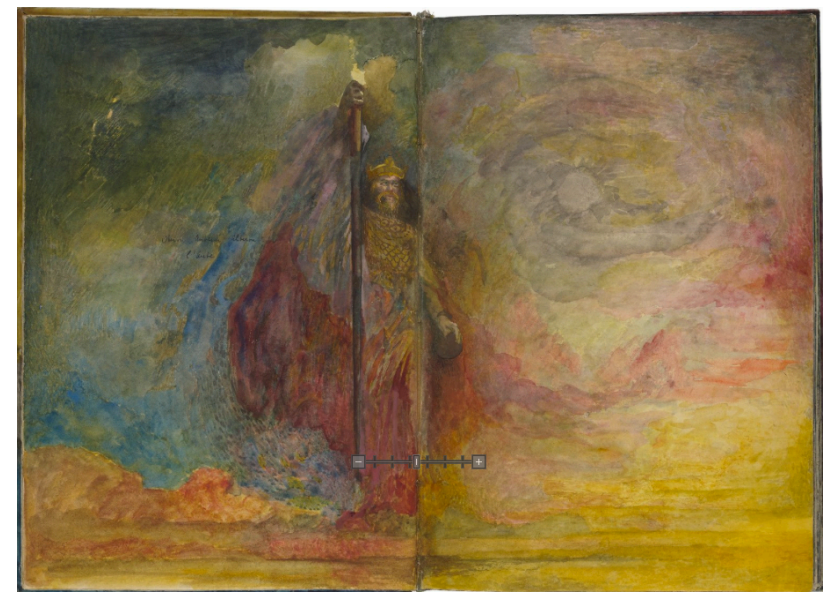

(Figure 2: Watercolor over A Midsummer Night's Dream, by Pickney MarciusSimons) to at least see where the displays would lead my design.

Pickney Marcius-Simons' version of A Midsummer Night's Dream was really fantastic. After seeing pages like this I knew that I wanted to treat the stage the same way. The concept was a simple one: saturated colors and a lot of texture. I wanted

to "paint" the stage as much as I could with my lights. That idea of "painting the stage" was important to me, and it would remain that way throughout the entire process. The Gladys G. Davis Theatre is a thrust where the audience is looking down on the stage. From that vantage point, the stage floor becomes just as important to a lighting designer as a backdrop would be in a proscenium theatre. I firmly believe that a lighting designer needs to treat that floor as if it were a cyclorama.

With a concept in mind, and one reading under my belt, it was time for a second read. The second read of the play, for me, is always the one where I start 
taking notes and highlighting things that will help guide the design. I never delve too deeply into specific concepts before the first design meeting because I want to hear what the director thinks about the script. The notes that I usually take are a series of questions that I have for the director. I had some smaller questions: how "bad" is the play within the play? Is there a specific time or feeling that we get from Quince's apartment other than it being different from the palace? Was everyone was onboard with my Hamptons sunset cocktail party idea. The one big question was what is the forest?

In a perfect world, the design team and the director would meet the semester before the show to discuss our design concepts. That was not the case this time around because Professor McGonigle, our director, was on sabbatical. That semester, I had also accepted a summer job with PCPA out in California, and I would be missing the first two weeks of school in the fall. So when it finally came time for our first design meeting, in August, I was not able to make it. We had planned for me to Skype into the meeting but Mr. Bigelow, the scene designer, was unable to get his camera working, so everyone just watched me react to what they were saying while I watched a blank screen and tried to look natural.

I can honestly say that I didn't really mind doing that first meeting from across the country. Sure, it wasn't an ideal way to have those discussions, but it did not change my process in the least. There are a lot of different types of directors that you come across, and everyone has their own way of communicating their ideas for the direction of the play. I've always just focused on the words. So I sat there and listened to what everyone had to say, and wrote down any words that seemed 
to carry weight when people spoke them. In the case of the forest, there were a few words that kept getting thrown around. To Professor McGonigle, the forest was realistic, natural, dark, wet, and overwhelming, but if you spent a little time in it, it would become comfortable. It was sexy, whatever that means for a forest. We kept focusing on the woods of West Virginia. The progression of the story reminded Professor McGonigle of his backyard, and how you become accustomed to a new place over time. That would be our forest. I remember ending that meeting and being satisfied with the results. It seemed like while we all had a lot of work to do, we were heading in the right direction. But designs need time to gestate and evolve, and it was during this process that I began to realize why we normally meet a semester early. 


\section{The Evolution of the Design}

I was unable to see the progression of the other facets of the design in their first few weeks. So, needless to say, I was very interested to get back and see the objects that I would be lighting. This design, for me, became a story of hurry up and wait. It would be hard to fully explain the evolution of my design without first discussing the evolution of the scene design from my point of view. My first meeting was with Jake Bigelow, the scene designer. Mr. Bigelow and I had similar thoughts initially about the direction of the world that we were going to be creating: $\mathrm{A}$ realistic forest that was swallowing the lovers and adding more layers of magic as the story progressed. A concept that, as we got deeper into the design process, seemed to diminish until we had a very necessary meeting late in the game.

The following picture is of the first version of the model. It had a lot of moving pieces, and certainly posed it's fair share of problems from a mechanical standpoint for lighting.

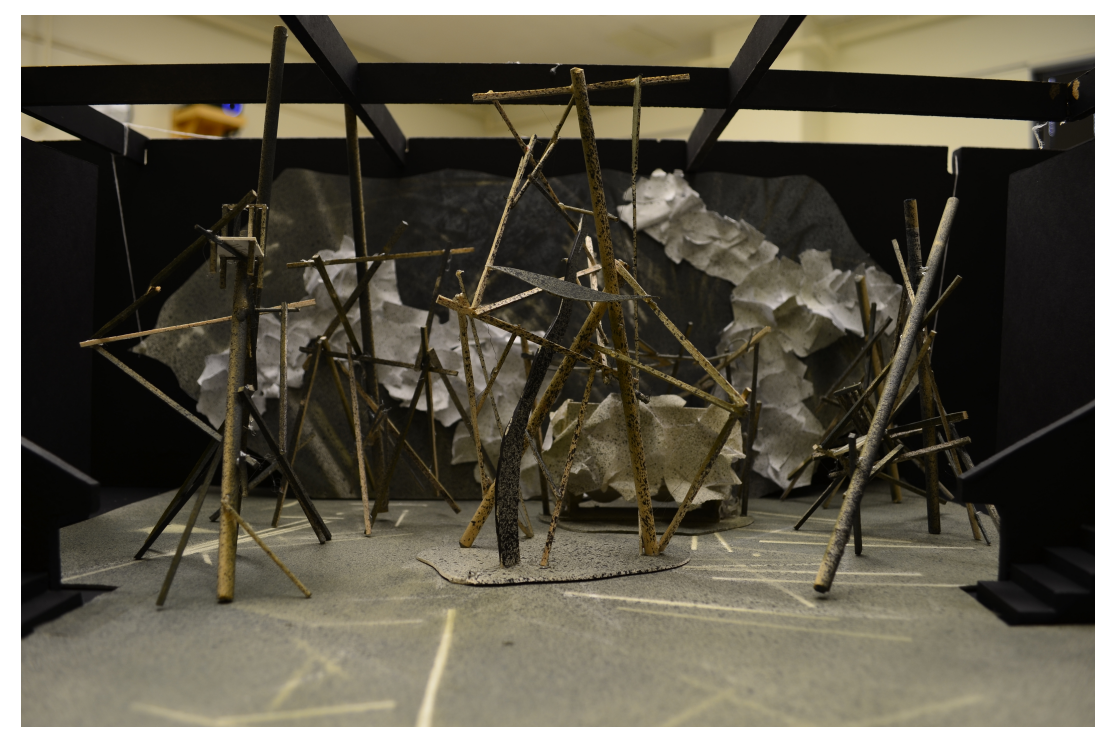

(Figure 3: Original model for the scene design for $A$ Midsummer Night's Dream, by Jake Bigelow) 
With a grid that stands only 18'-0" off of the deck, I was concerned that having set pieces so close to the ceiling would make it tough for me to find successful lighting angles in that space. This isn't something that I would vocalize this early in the process, mainly because I honestly believed that I could make it work given some time to brainstorm. My bigger concern was that it looked like we were moving away from our concept of a natural realistic forest. One of the things that I struggle with, especially in such an academic setting is when to voice design concerns and when to keep to myself and allow for the design process to run its course. Mr. Bigelow is a MFA student just like me, so I chose to keep quiet in order to allow him to go through his process. If this is the "world" that our director wants this play to take place in, then I will design for this world. Professor McGonigle seemed to share my concerns. He had asked for a more natural set.

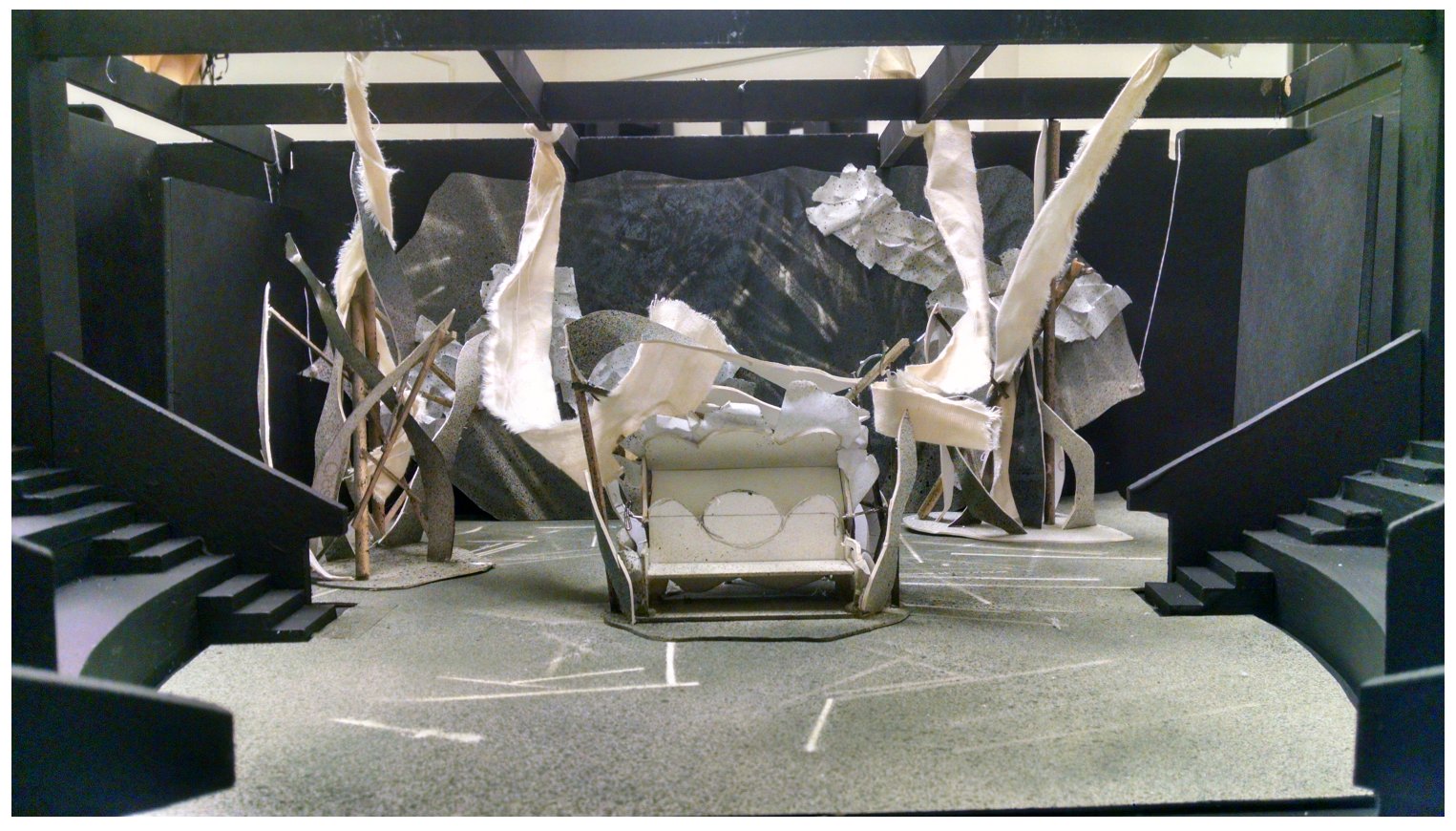

(Figure 4: The second version of the model for the scene design of A Midsummer Night's Dream, by Jake Bigelow) 
The second model saw the addition of leaf-like flaps to the original structures, fabrics that would hang straight down to form a colonnade or tie off in the forest scenes, and the bower with a canopy that could open at center stage. The tough thing about this process for me was feeling out of the loop. I would sit in on meetings that Professor McGonigle and Mr. Bigelow were having from time to time, just to make sure that I would be able to put my two cents in. But for the most part, I would just rely on recaps and redesigns from Mr. Bigelow to see the progression of the set. This show served as a perfect example of how a shortened design period can hamper the design process. I think for the majority of the time, the design team and Professor McGonigle were searching for what this show was. It felt like we were throwing darts at a dartboard for a while, or trying to pin the tail on a design concept.

It finally came to a head when we had a meeting to really discuss the design. I don't remember how late in the schedule we met, but I do remember it being right around when the scenery build was supposed to start. We had already done our final design presentations for the entire design team. The question posed to Professor McGonigle was simple: What do you need to do this show? Do you need anything to do this show? Then I was asked if I could light this show with out any scenery. My answer: "I think it would make a really interesting thesis, but I would rather not." If it were another show, maybe I would have said yes. But throughout this process I always felt that I needed elements of a forest to add my light to. At the end of that meeting, we all decided to go back to our original research and base our designs off of that. Trust your research. If I were to make a shortlist of lessons that I 
took from this, "trust your research" would be in heavy contention for the number one spot.

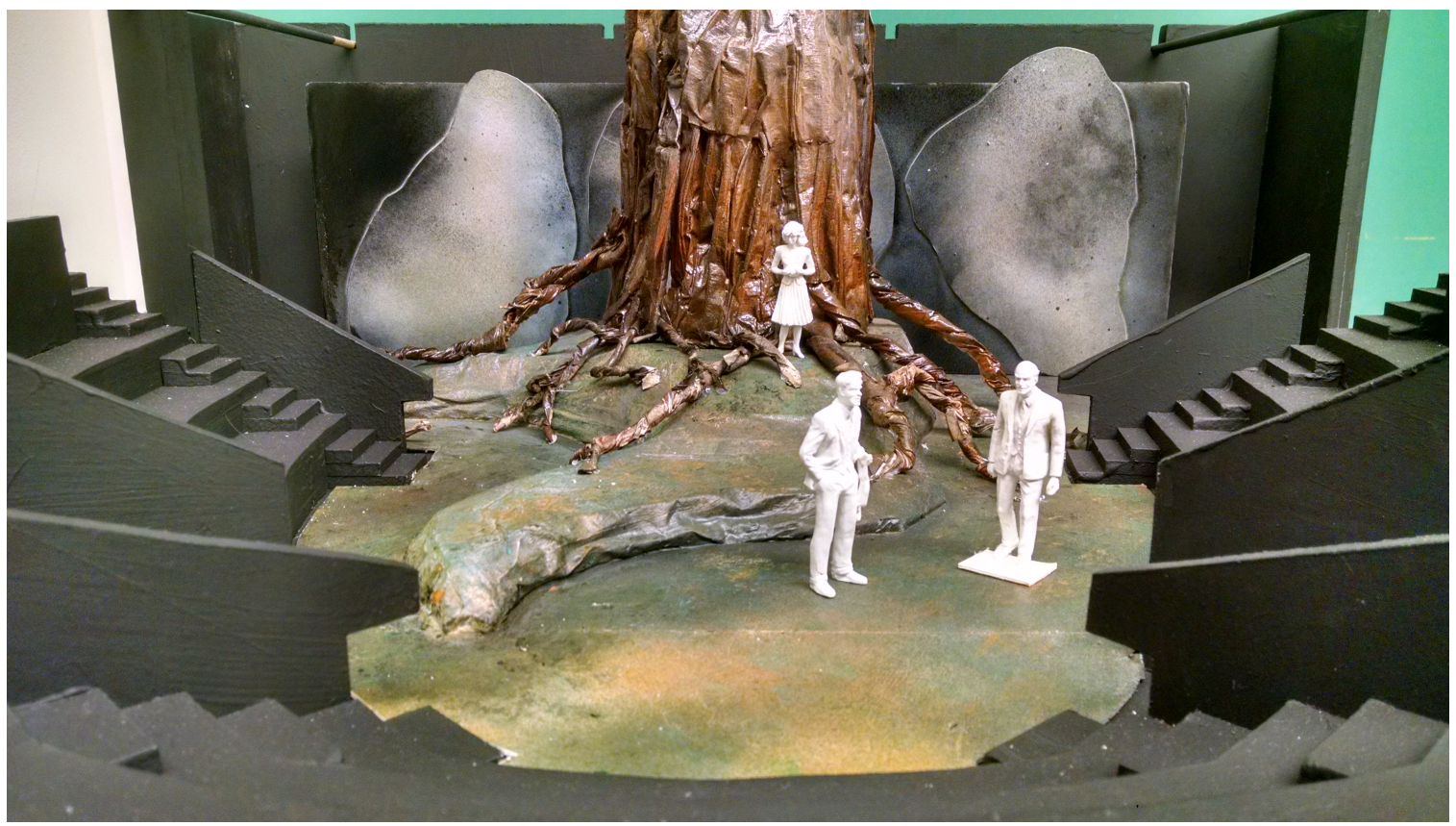

(Figure 5: Final version of the model for the scene design for A Midsummer Night's Dream, by Jake Bigelow)

The photo above is of the final model, the one that most closely resembles the set for our show. Once this was made, and approved, I could finally begin my design process. At the beginning of the design, I always start with either angle or color. It comes down to which one I feel is more important to the design. Color was a landslide victor in that race. In addition to my initial concept of "painting" the stage, the architecture of the theatre doesn't exactly lend itself to a wide variety of angle choices. Too shallow and you will blind the audience, to steep and you won't get the coverage or visibility that you need. I had the benefit of watching and loading in two years worth of shows in the theatre before finally attempting it myself, which was a lucky break in hindsight. 
I genuinely love doing lighting research. There are some really amazing photos out there. I spend a lot of time thinking before I ever go searching for photos, because I think it's important to have an idea of what you are looking for. What I was looking for were examples of semi unrealistic night forest scenes, strong texture and shadows, use of fog and haze, and a sunset that was realistically captivating.

These three photos were perfect examples of the texture, color and quality of light that I had been looking for. Ever since Professor McGonigle had described his world as dark, wet, and overwhelming until you had time to get used to it my mind kept going to the same place. But how do you tell your director that you think our forest should be Dagobah without showing him a screenshot from The Empire Strikes Back. That's when I came across the last photo (figure 8). I included this photo for strictly emotional reasons. It evoked exactly what I wanted the audience to feel as the watched the show. I feel like this setting gives you just enough to worry about. You're just not quite sure what you'll come across. Also, the haze level was great.

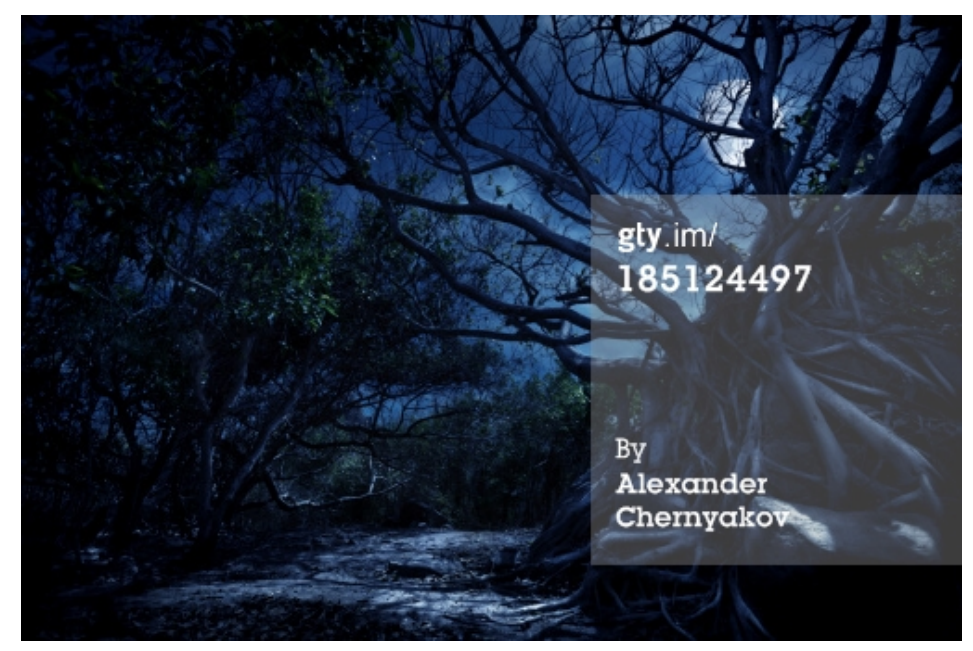

(Figure 6: Forest research taken from Getty Images) 


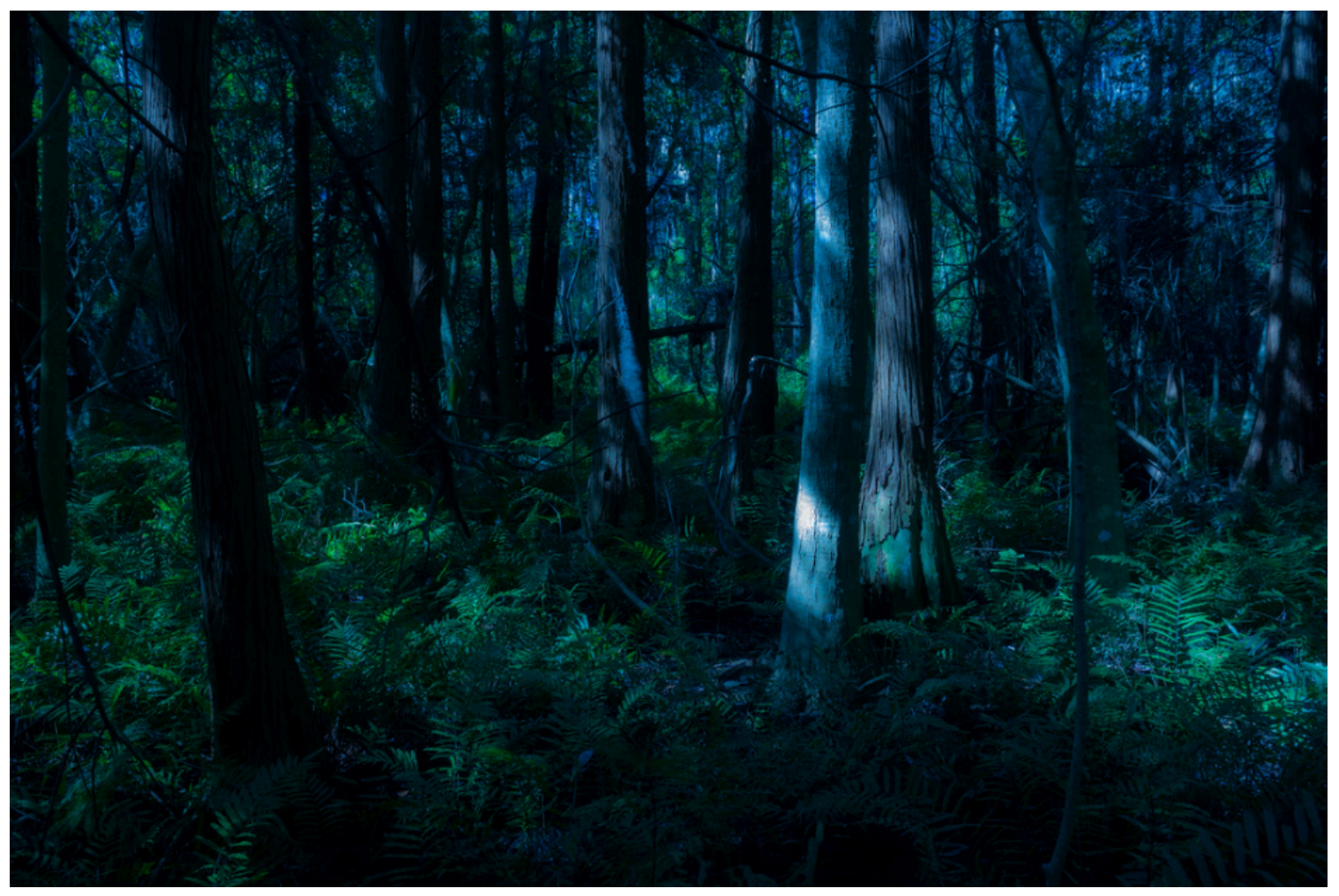

(Figure 7: Forest research taken from Flickr)

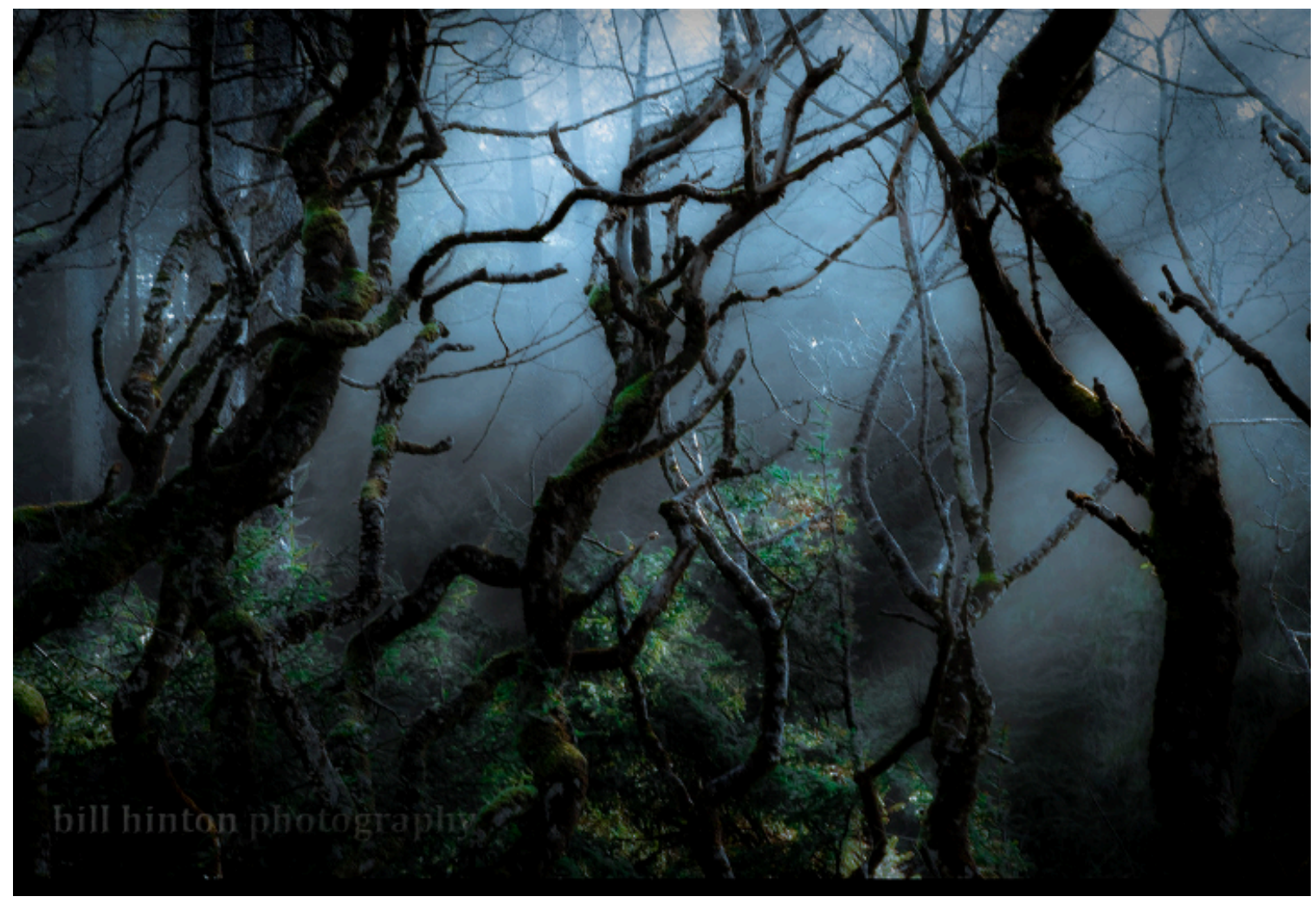

(Figure 8: Forest research taken from Flickr) 
Next, I needed photos to show how I was planning on using specific texture for certain moments. Mr. Bigelow had this great research photo where there was a giant tree and it almost looked like it was a forearm. And the roots of the tree were fingers on a hand, as if it had literally planted itslef by just grabbing the earth. I thought it would be interesting to carry that motif through my lighting design as well.

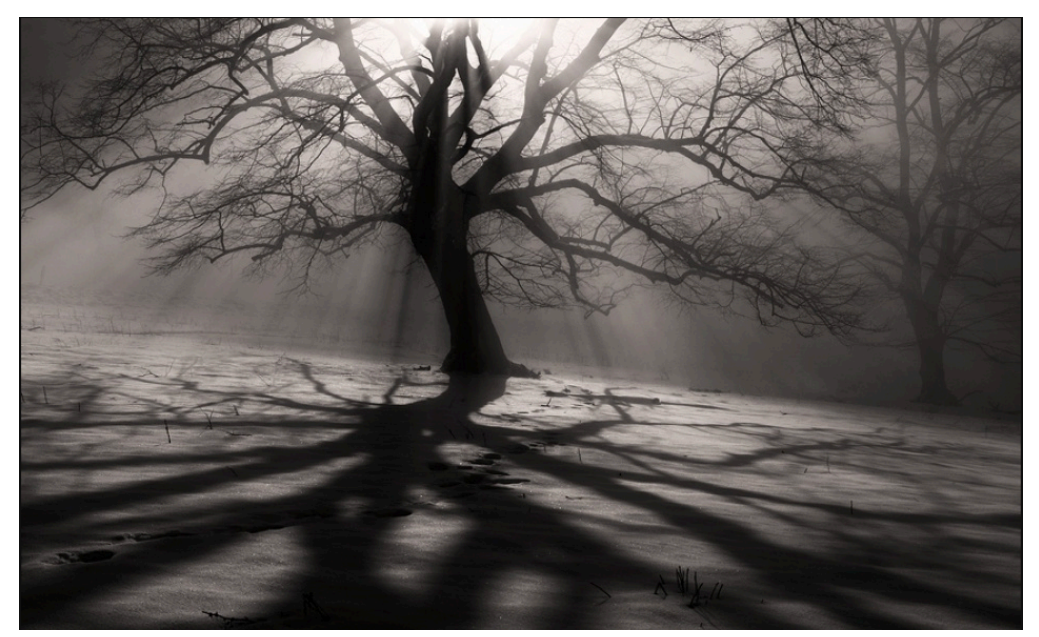

(Figure 9: Forest research taken from Flickr)

I needed a way to show progression throughout the play. There are several scenes that take place in succession that are happening in different parts of the forest, and there were no scenic elements that would be changing around the cast. So what if there were these shadows of bare branches. Yes, I know it's the summer, but there are also faeries everywhere so I feel like I can take some liberties. The bare branches almost look like gnarled fingers. As the lovers get deeper into the forest, the "fingerlike" branches cover more and more of the stage. So with each new scene I would add another system of branches to the mix. As if to say that as the play goes on, the lovers are continuously further in the mischievous grasp of the forest and it's magic. 
Lastly, I needed my sunset. I had already decided that I was going to write a 25-minute light cue that would take the audience slowly into the moment just before the sun has finished setting. That cue was during preshow, and it was $100 \%$ for me. I think that I was the only person in that room who noticed the shift. I didn't expect any audience member to be paying attention enough during preshow to notice that.
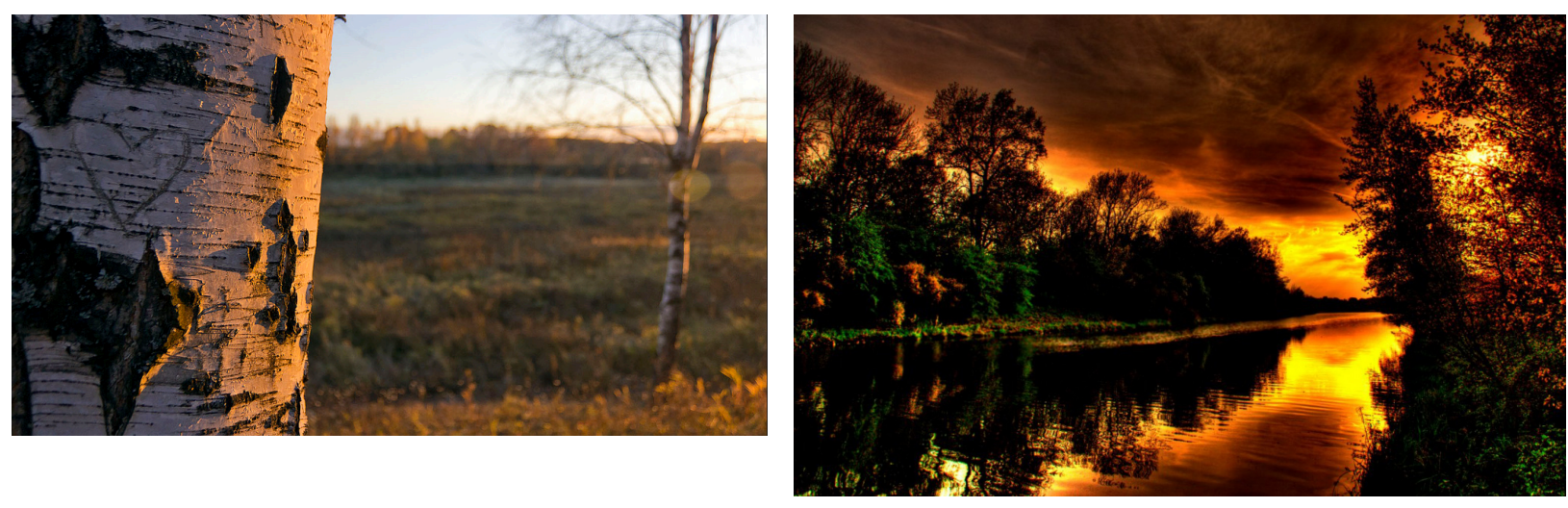

(Figure 10: Sunset research images taken from Flickr)

This was the first show where I really pressed for paint samples from a scene designer. I really wanted to spend a lot of time with the samples, and test a lot of different gels. I set up a rolling "light lab" on a cart, outfitted with a small portable dimmer rack, 4 PAR16 lamps and a fader console. The PAR16s were all on separate faders, and I spent many hours testing gels. I wanted to see how my color choices would affect the paint treatment. I also wanted to see how each one affected my perception of the other gels, and if they created an aesthetically pleasing contrast on three-dimensional objects. Last, and most importantly, I needed to see what the 
colors looked like as I lowered their intensity. I knew that the forest was going to be fairly dim. That, to me, is the beauty of doing something in a more intimate theatre. When the audience is closer, you can use less light with your looks. I really hate it when objects on stage are too bright. I also knew that it was going to be a blue- heavy show, and so I wanted to pick colors that reacted well to lower intensities and didn't turn muddy during any "amber shift" that will occur when a light is on at a low percentage. Amber shift is something that occurs in incandescent lamps as they change intensities. Simply put: as the intensity of the light lowers, the quality of the light will become warmer and more amber. I had also decided that because I was going to have so much saturated light coming from my wash systems, that I was only going to have one system of front light. Again, the 3/4 thrust really dictates where you are going to be placing your lights, so I put all of my systems on a $45^{\circ}$ angle so that each bank of audience would get the same amount of it. Then I would have one system that was straight front from each of the three angles that the audience is facing, as shown in my lighting key (Figure \#11). I needed to make sure that the color that I chose for the front light would not only dim well, but additively mix nicely with the colors that I had chosen for my saturated washes. I was so happy with how this process turned out, that I will swear by it for future designs. It was also nice to have the mobile light lab set up throughout the design process so that we could look at updated samples under the colors I was planning on having.

Professor McClung, the costumer designer, is really fantastic to work with. She always gives the lighting designer so many great colors and textures to work and play with. This show was no different. Thanks to the light lab, we were able to 
look at costumes as they were being constructed to make sure that we were still on the same page. Which is a nice way of saying that the colors I had chosen weren't going to ruin her design.

As soon as I had a ground plan from the scene designer, the plot came together fairly quickly. I knew I would be going with 8'-0" acting areas based on the inventory available. The theatre and set were both oddly shaped, so I just started drawing circles until I achieved the coverage I needed. This was not a show about small areas and isolation, so control was never an issue. Running out of twofers was definitely an issue, so I did need to keep an eye on that. We had 90 available dimmers in the grid of the theatre, and I used every single one. I also used all 43 twofers that we had in stock. Large open areas require a lot of instruments, and I was concerned about dark spots and being able to create a smooth transition between areas. So I made sure that my coverage was more than sufficient and chose a slightly heavier frost (R114). After figuring out most of the design, it was time to turn my attention to the tree. I knew that I had to assign instruments specifically to light the tree. From the start, I had decided that I would use my budget to accomplish that task. 

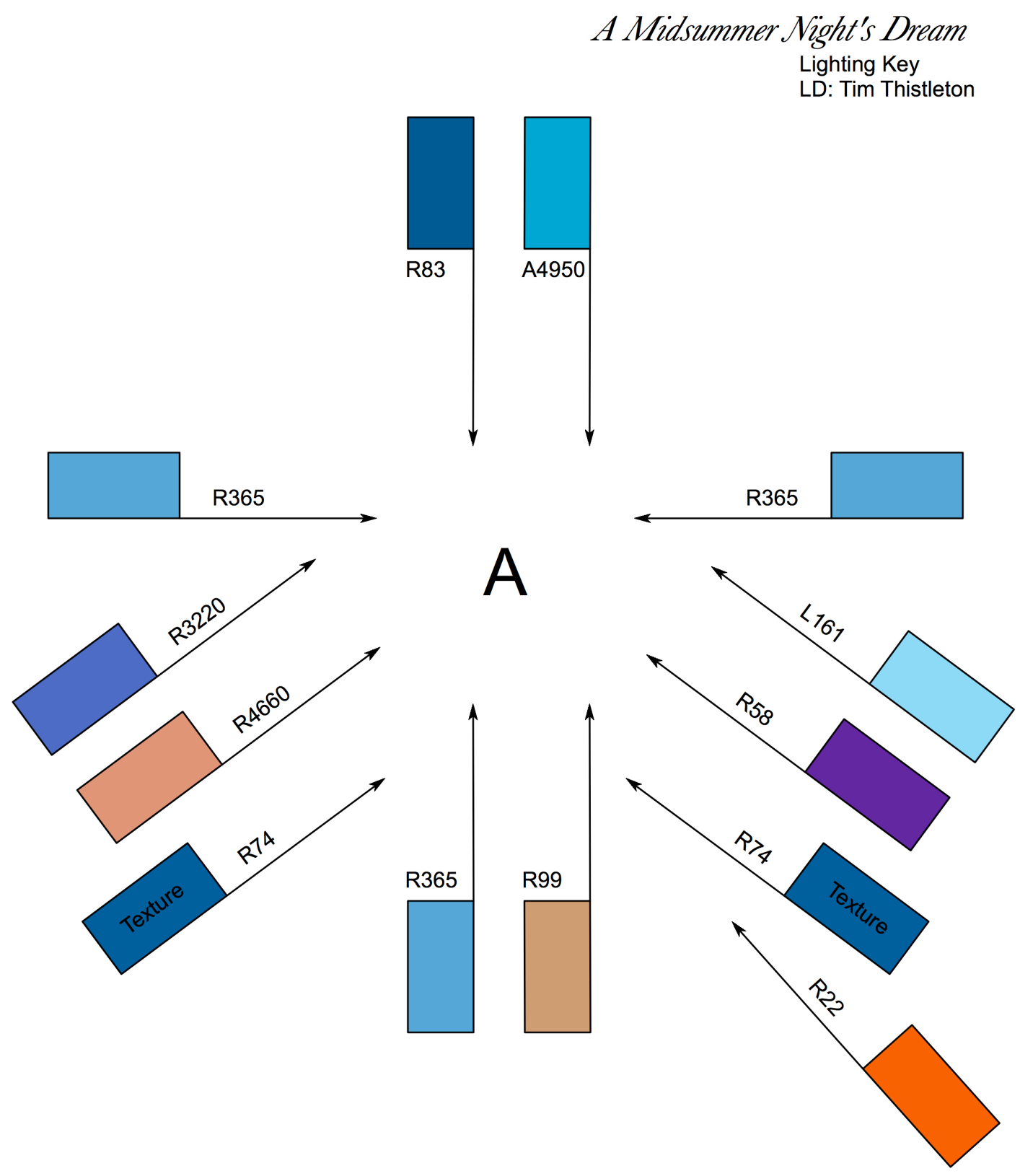

(Figure 11: Lighting Key for A Midsummer Night's Dream, by Tim Thistleton) 


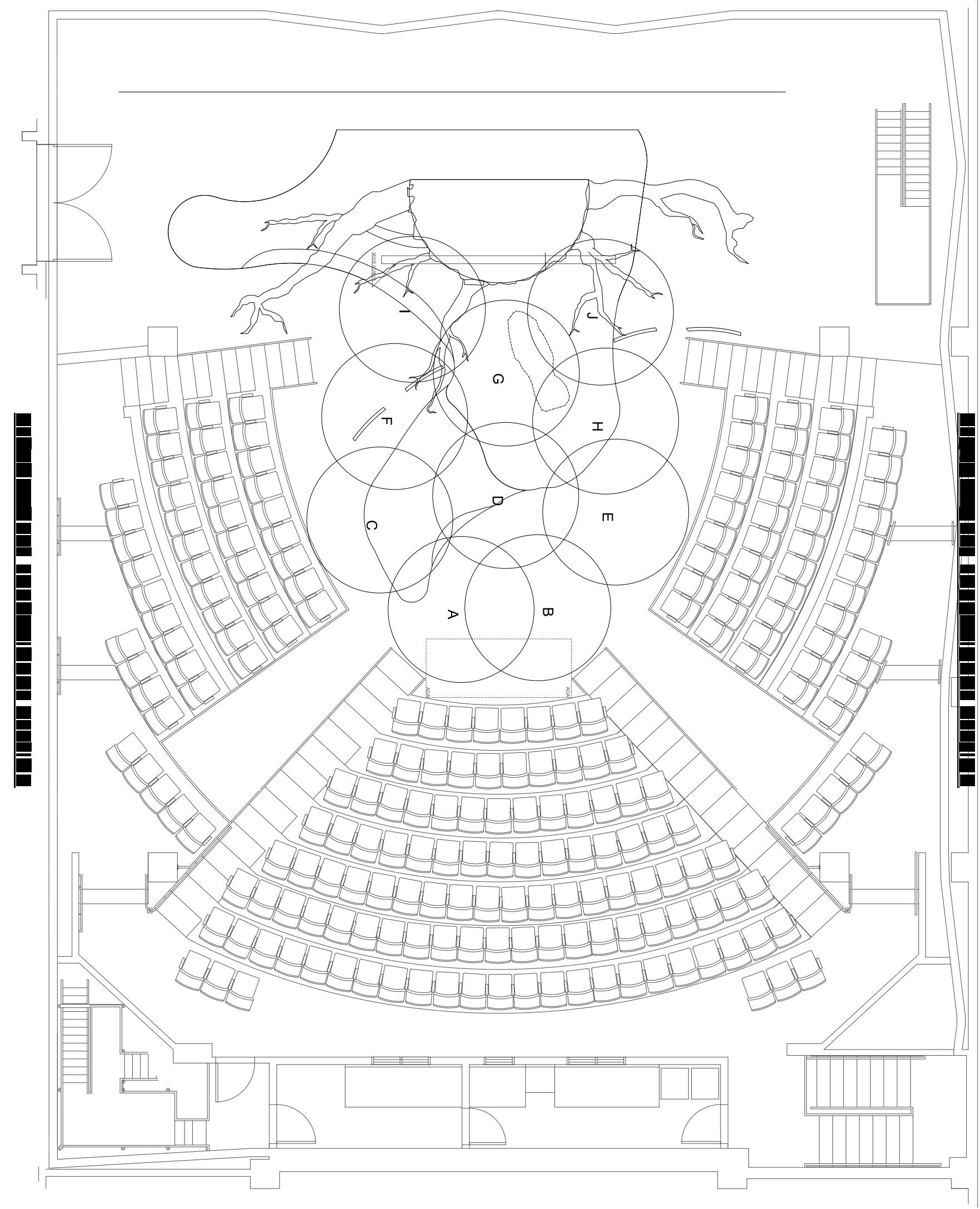

(Figure 12: Acting area layout for A Midsummer Night's Dream, by Tim Thistleton) 


\section{The Budget}

I was given a budget of $\$ 750.00$ for this show. Which sounds like more than enough when you already have the majority of the instruments you need in house. I had already spent my first $\$ 100.00$ on $1 / 3$ of a wireless dimmer for the department. The lighting designers for the semester had all agreed to kick in a little from each of their budgets so that the department could purchase a reliable wireless dimmer setup. So my spending limit began at $\$ 650.00$. I always want to save at least $\$ 300.00$ for color and gobos, so my goal was to keep my spending to $\$ 350.00$.

There were two major effects that I had saved for my budget. The first was lighting the tree. My initial thought was to light the tree like a cyclorama, and I wanted flexibility and the option of color mixing. I began to price out LED fixtures that I could rent. I first looked at the Color Kinetics ColorBlaze striplight. The ColorBlaze was an instrument that I had used over the summer, so I knew it would give me the color choices and punch that I needed. I would need three of them to fully wrap around the tree, and at $\$ 150.00$ a week per unit, those were out of the question. Scheduling played a big part in negotiating a rental agreement because the show was going to split Thanksgiving break, which meant that I would need anything that I rented for an extra week. Next I looked at the Color Kinetics Color Blast, a smaller 1' brick option similar to the 6' ColorBlazes. They would have cost only $\$ 50.00$ a week per unit, but I would have needed to rent several more to light the tree evenly. Based on the drafting, I had calculated that the circumference of the 
front half of the tree was roughly 18'. The last LED fixture that I looked at was the newish ETC LED Source Four.

I figured I would want at least three of them to fully cover the tree, and it wouldn't be lit with the downlight similar to a cyclorama. But if I chose a busy enough texture and overlapped the focus enough, you wouldn't see any annoying shadows from actors when they stood near the tree. The Source Fours were $\$ 75.00$ a week per unit. Because of Thanksgiving, I would need them for a month. I decided to step away from the LEDs and look at incandescent fixtures. I finally decided to go with the Altman 6' Mini Strips.

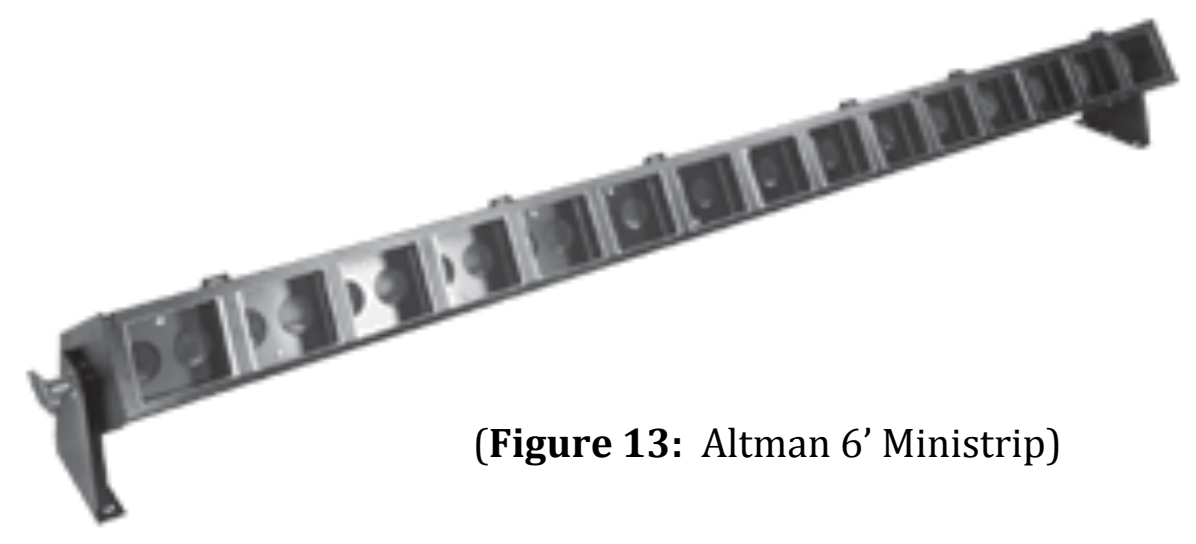

I would need three of them, and they cost $\$ 50.00$ a week per unit. Vincent Lighting Systems (VLS) has always been a pleasure to work with, and they seem to really take care of their regular customers. Normally for a month-long rental, the Mini Strips would cost $\$ 125.00$ per unit, for a total of $\$ 375.00$. VLS was able to give me a discounted price of $\$ 325.00$. Meaning I would still be on budget.

The second effect that I wanted to implement was thick low-lying fog for the penultimate forest scene. There is a moment in our text where Oberon says: "With 
drooping fog as black as Acheron, And lead these testy rivals so astray..."

(McDonald, 56) We had spoken in earlier meetings about how the tree was such a focal point that it was as if the magic were emanating from it. I thought it would be a really great effect to have the fog come out of the base of the tree and then roll down the hillside, filling the playing space. The department owned a homemade dry ice machine, made out of a 55-gallon oil drum. So I would only need to supply the dry ice for the effect. Through some tests, I calculated that it would use roughly one pound of ice per minute that it was on. I wanted the effect to last for 5-10 minutes. We were going to have 18 performances including tech and dress rehearsals due to the addition of several matinees to help bankroll scenery being over budget. I had originally been quoted $\$ 2.00 / \mathrm{lb}$ for the dry ice, which means I would have needed another $\$ 400.00$ including what I had spent on the tests, and the dryer hose that I used to aim the fog. When I went to go purchase more dry ice for a second test, I was charged 50 cents a pound. I decided it would be best not to ask any questions and hang onto that receipt for future purchases.

I decided that I still needed to cut some spending to allow for the purchasing of the dry ice. And honestly, at $\$ 12 /$ each, gobos are too expensive. In a perfect world, I would buy specific gobos for every show, always boosting my inventory. But I can also make do with trees that aren't exactly perfect. In the grand scheme of things, it shouldn't ruin your design of a tree gobo has just a few too many branches. At least, I hope not.

What all of this amounted to was leaving myself with around $\$ 200$ for gel and some "just in case" money. Because I had put such an emphasis on my color choices 
this time around, I found myself needing to buy more gel than I have in the past. I was making strong decisions instead of choosing whatever colors we already had in stock. I wasn't just choosing the best color out of what other people had used in the past few years. This play for me was about a change in how I prioritized aspects of the design, and that is certainly where I saw the most personal growth. 


\section{Technical Rehearsals: Cutting Your Losses}

Lighting design is a funny art form when you think about it. I spend the majority of my time planning for the unknown. You spend countless hours picking what you think will be the "right" instruments. Instruments with the right color, and the right gobos, hung in the right place in order to light the right location on stage. Thankfully there are several tools that help us to make educated decisions weeks before we ever get to hang a light. At the end of the day, you have to trust the tools and materials that you've been given and prepare to be flexible.

I love getting samples: paint samples, costume samples, any sample that is offered to me. Samples give you the opportunity to test your color choices against the objects you will be lighting. Another useful material is a ground plan: a "birds-eye-view" drawing of the set showing where all of the scenery will be placed (figure 14). With the help of a ground plan and a couple of meetings with your director, you can start to figure out where the majority of the action will be taking place in the context of the environment. This was very important to me. The theatre where we were producing the play is outfitted with 96 dimmers. What this means for me is that I can only have 96 individually controlled lighting instruments in my design. While that sounds like a lot, they get used up quickly as you start to plan out all of the different looks that you will need in order to support the text. This all boils down to making the most out of your theatre's inventory. Every theatre will have its constraints, and it's good to know heading in where you will need illumination and where you might not. I was able to see one rehearsal prior to 
tech: a run-through that was in another space. It was enough for me to get an idea of where my cues would be placed, and how the show would flow from scene to scene.

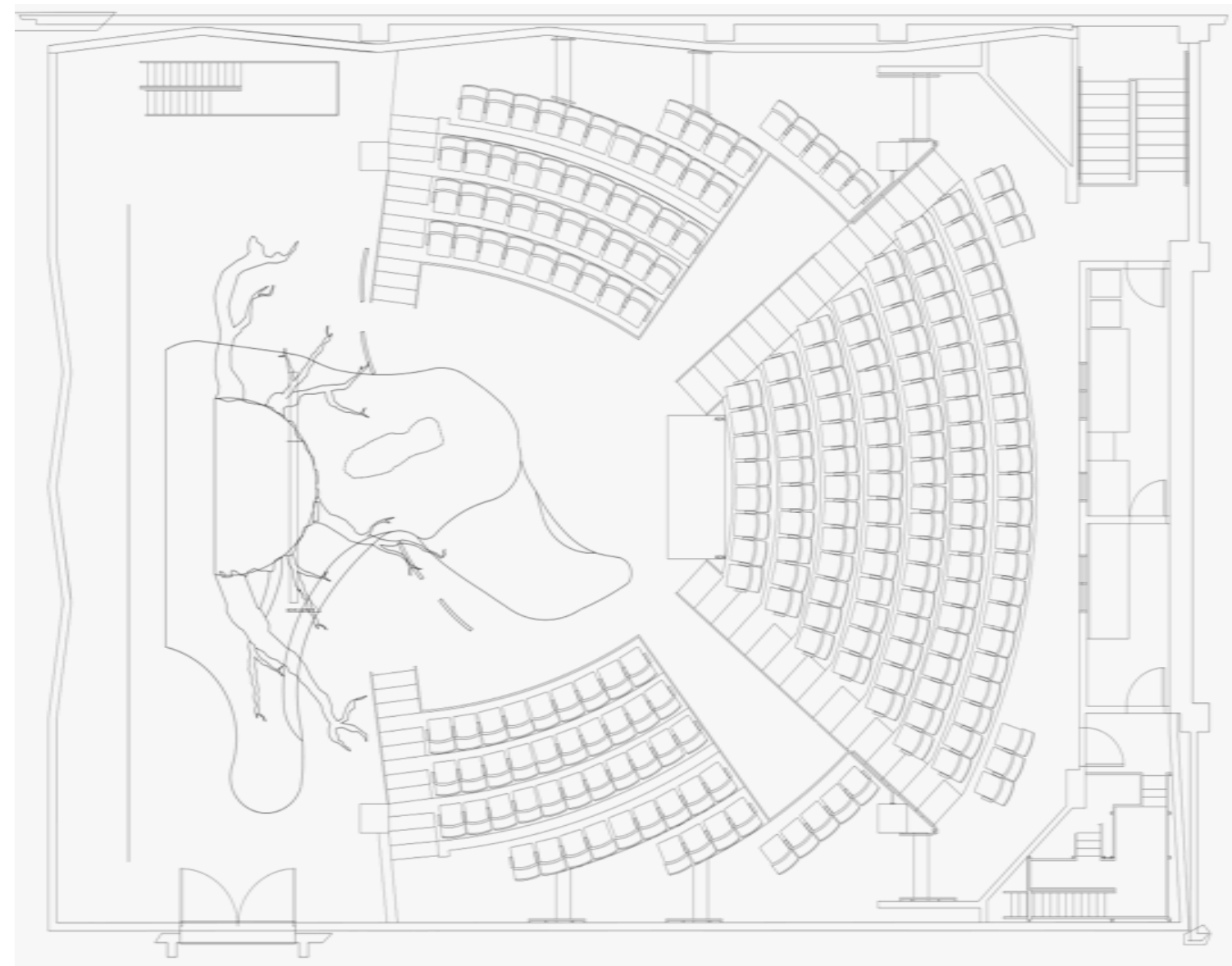

(Figure 14: Ground Plan for A Midsummer Night's Dream, by Jake Bigelow)

With all of this preparation behind us, we were ready for load-in. The load-in for this show was a smooth one. A quick tangent on my crew: For the first time in my career I was working with both a master electrician and an assistant lighting designer. James Brown, my master electrician, and Tyler Cooper, my assistant lighting designer are two former students of mine from my fundamentals of lighting 
class and, as of writing this, are enrolled in the undergraduate technical theatre program at WVU. I said from the beginning that this process would be as much about their growth as it was about mine. We met a few days before load-in and I explained to them that I was going to treat them like a professional crew, and that I was going to expect professionalism in return. To their credit, they did not disappoint. We were able to stay consistently on schedule throughout the load-in process, and that is thanks to those two gentlemen and their ability to lead a crew of freshmen technicians who we being introduced to lighting for the first time.

Staying on schedule was particularly important for me because we were waiting on two larger effects that would need to be loaded in at a later date than our load-in start due to money and time, two things that come at a premium. Scenery was slightly behind schedule with their build. There was a Saturday when I came in and just carved foam all day. I'm here to collaborate and put on a show, and I'll do whatever is needed to make that happen.

The first effect that I wanted to start on was my dry ice fogger. The idea was to produce the fog from the base of the tree. It's usually helpful to have a tree before you can work on something like that, so once the scenery was in place, I started to run a dryer hose around the inside of the base of the tree. The tree was coated in chicken wire and muslin, so all I had to do was attach the hose around the framing and then cut holes through the muslin and the hose. I also needed to find a place to hide the dry ice fogger itself.

The fogger was a 55-gallon oil drum that had heating components added to it in order to transform it into a dry ice machine. Luckily for me, the tree was hollow 
and gigantic. We filled the fogger with the necessary amount of water and patiently waited for it to heat up. Once it was at temperature, we dropped eight pounds of dry ice into the basket of the drum and closed the lid. I ran around to the other side of the tree so that I could take a look at our effect. There was a lot of fog. Of course, it was all inside the tree, so I couldn't see any of it. We spent the next part of our day, trying to troubleshoot the dryer hose and the path of the fog. What we finally settled on was three large holes spread evenly along the base of the tree. Every other hole that we had made was patched up, and the three holes that we kept were enlarged and tunnels were made so that the fog had nowhere to go but out of the tree. We also grabbed scrap duvetyn to blanket any seams that might have existed in our hose or tree.

I went back to the store and bought more dry ice. This time, I purchased twenty pounds. We filled the basket as much as we could, and tried again. The result was underwhelming. I had a very specific idea in my head about how I wanted this to look. I wanted the fog to be released, almost exhaled, from this tree. The fog would then roll down the hill that the tree was perched on and fill the space. Then the lovers, lost in the forest, would be moving around this amazing low-lying fog as they attempted to find each other to no avail. What the fog did instead was sputter out of the tree and then go straight up into the air. The fog wasn't low-lying enough, and there wasn't enough pressure to get the fog to really move. I think that I was asking too much to have the dry ice machine push the fog through the series of turns that the dryer hose needed to take. Another factor in all of this was our inability to control the airflow in the theatre. I wanted something with a $100 \%$ 
success rate, so we started to rethink the effect. I scrapped the dry ice machine, but left the hose. The dry ice machine didn't hold enough dry ice to create the effect I wanted, the fog came out too weak, and it dissipated too quickly. We had a fogger in our inventory, and we had a gallon of long lasting fog fluid. We still needed a way to cool the fog in order to get it to remain low-lying, so I packed dry ice into a tube that the fog would have to flow through on its way to the hose. The result was promising, not ideal, but enough to give me hope. The fog came out with some force behind it, and it did roll down to at least the second level of the set. I still wanted more, and the fog machine had its own set of problems, although these were all noise related. Our fogger was loud, noticeably loud. I wanted to tackle one thing at a time, so we tried one more thing. One of my fellow graduate students had recently constructed a valve system for using a tank of $\mathrm{CO}_{2}$ to cool our fog machine. If I thought that the fogger was loud, the pressurized tank of $\mathrm{CO}_{2}$ was deafening. That is, of course, an exaggeration, but I think you get the point. I had a problem, and I did what any sensible person would do. The next day I went to see if someone else could hide it. I talked very briefly with Alan McEwen, our sound designer. There wasn't a sound cue for that moment in the show, and there really wasn't any motivation for one to be added. I always knew that was going to be the answer. It was a long shot that I needed to take.

We tried the fogger without the $\mathrm{CO}_{2}$ cooler one more time with actors during tech, just to see how noticeable the noise would be. Surprisingly enough, this time not only was it noisy, but it was warmer in the theatre than it had been before and the fog went straight up into the air and blocked our view of Oberon during his 
monologue. That's the gamble of trying this effect during the winter. Sometimes the heat is on in the building, and like I said, that is not something that we can control. I had said from the beginning that I was not going to have an effect in this show if it wasn't going to be exactly what I wanted. I truly believe that if the effect had been right, it would have been an amazing moment in the show. But if it was going to have to be one of the three permutations that we tried, it was going to be lackluster and underwhelming. I cut the fog altogether. I refuse to put a product out there that I don't feel confident about. And I was not about to ruin a moment in the show with a mediocre attempt at weak fog seeping out of a tree.

One of the other things that I changed very early in the process was my front light color. I had spent a lot of time carefully picking out every color that was in the show. Especially the front light color, because I was looking for something that would additively mix with the rest of the colors nicely, and also still look blue when it was dim. Due to the amber-shift that I wrote about previously, cooler colors sometimes become a little "muddy" or ugly as they dim to lower intensities. The color I originally had chosen was Rosco 360 , which is called "Clearwater". It was really great during all of my tests on the set treatments, and it held its blue tone consistently through the dimming process. It brought out some really wonderful notes that were part of the scenery's paint treatment, and helped to create the feel of a forest at night. It lasted for roughly a minute of tech. It turned everyone's skin a wonderful shade of green, as if they were underwater. I should have paid closer attention to the name. I gave my assistant designer a range of colors and also asked him to look around in the shop and grab some colors he 
thought might work as well. As soon as we had a break, I had him go to a light and start looking at the colors he had picked out to see if we could settle on a new color. I quickly decided that we would use Rosco 365 instead. "Tharon Delft Blue", named after legendary lighting designer, Tharon Musser. The gel had all of the qualities that I liked about the Rosco 360, with none of the green tint. Color changes are always to be expected, it's why you should never be married to the idea of a specific color. It's all just part of the educated guessing game. The last lights that we loaded in were the three Mini Strips that I had rented from Pittsburgh. In order to save the money, I had picked them up for the second week of our load in. They were easy enough to install, and I already had the necessary power run to where they would be plugged in. Because of the nature of the grid squares and the movie screen that was in our way (Figure 15) I needed to hang the lights lower than any of the other lights. It was something that I had noticed a couple of weeks prior and had already spoken with the director and the scene designer about. I made "tail-downs" quickly out of c-clamps and threaded rod so the lights could hang at the necessary height. I knew exactly what colors I wanted to use in the strip lights, and I had added diffusion to make sure that everything would blend nicely. We plugged them in, turned them on, and the tree looked amazing. 


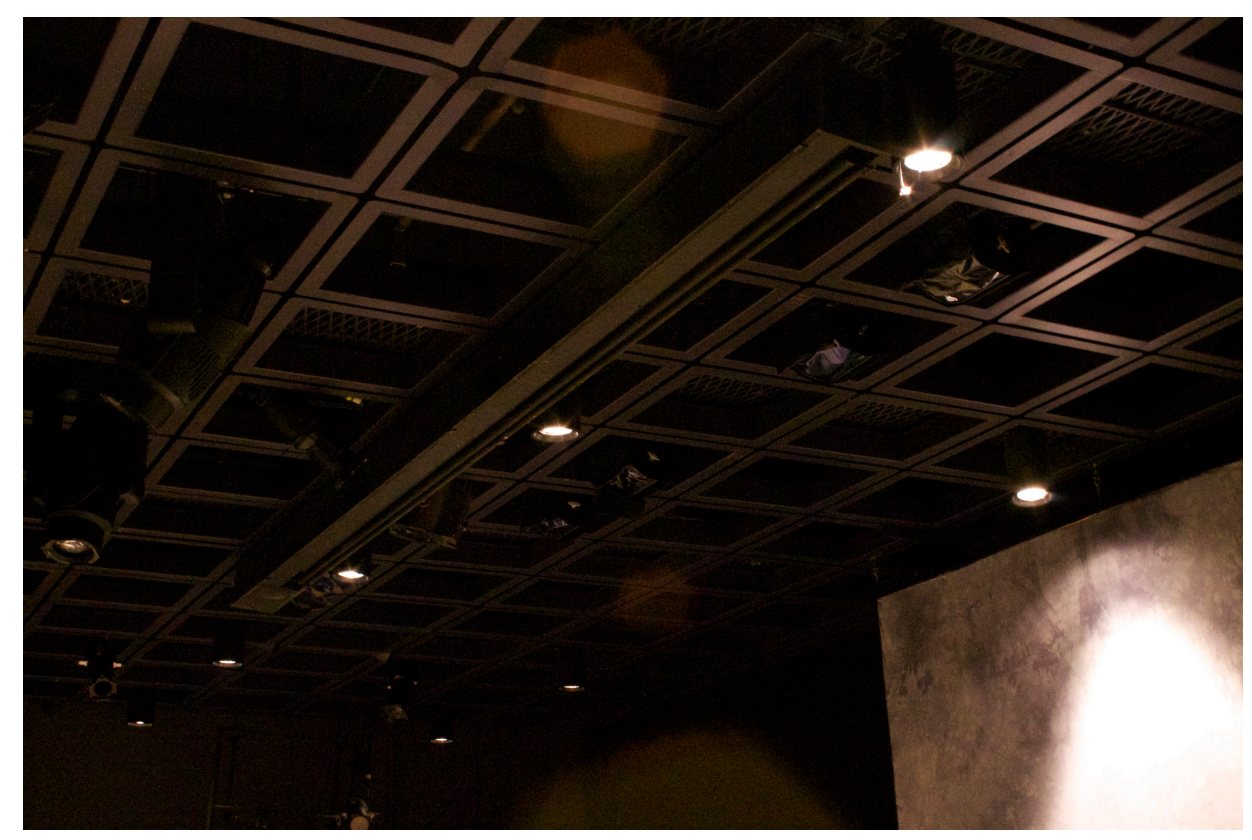

(Figure 15: Photo of the movie screen attached to the grid of the Gladys G. Davis Theatre)

As I went through cuing, there were some looks that I was really proud of. When we got to our first forest scene during tech, there were some "oohs and ahs" from the actors, which is always nice to hear. I really felt like I had nailed it with the strip lights. Towards the end of the day, the director came over and asked if there was anything we could do about raising the strip lights because they were becoming a part of the environment of the play. I stepped away from my desk and started to walk around the house and look at the show from a few different audience angles. There were sections as you got closer to the stage that really saw the source of light, so it took on the aesthetic of a rock show instead of Shakespeare. The lights definitely needed some black wrap, which is what we use to shield portions of lights that may have light leaks or spill on to the set. In this case, what we needed to block were the sides of the lenses of the strip lights. They were way too distracting. The 
other thing that the director had noted was that the strip lights, while beautiful, created a frame for the tree. He was right; there was no theatre magic to this tree. It clearly ended where this black bar of strip lights began, instead of just fading away into the blackness of the grid.

The key to successful lighting often lies in focusing on the basics. I teach my students the importance of the five functions of lighting design. Selective Visibility, which we have already talked about, is lighting the areas of the stage that are the most important at any given time in order to direct the audience's attention. Mood is all about creating an emotional atmosphere for the play to exist in, while supporting and enhancing what is happening on stage. We've also already talked about Information, which is using the lights to show the setting of a particular scene, along with time of day, and year, and anything else that affects the quality of light. Modeling is very simply taking a three-dimensional object and lighting it three dimensionally. You don't want to flatten any of the objects on stage from any point of view. The last function that I teach is Composition. Composition is about the overall picture that we are creating on stage. It's important for all of the other functions to marry, creating a cohesive design. It's also important for the lights to support the other designer's work. Lastly, when you take a step back, and just look at the stage as a whole, does everything fit and make sense. When I'm designing lights, I make sure that each light tells a story. I ask: "What is the truth of that light?" As I looked at that stage, the strip lights broke the reality of that show. Not to say that Midsummer is realistic, but those lights were not meant to be a part of that world, and they were an impedance that affected the audience's ability to suspend 
their disbelief. I cut the strip lights; something that I would not have done so quickly a few years ago. A younger, more immature, version of myself would have found a way to wrongfully rationalize the use of those strip lights. I would have backtracked my design concept to allow for visible lights, and I would have been stubborn about sacrificing what was a good lighting idea for the good of the play as a whole. It all would have been for no reason other than laziness. That's a really good way to do mediocre theatre, and if you take one thing from this chapter, I hope it is that I am past the point of settling for mediocre theatre.

I still needed light on the tree, it was a giant piece of scenery dead center, kind of hard to ignore. I used the dimmers that I was using for the strip lights to hang what we had left of our $50^{\circ}$ ETC Source Four fixtures. I placed the same colors in the new lights as I had in the strip lights and I added leaf-like gobos to all of them to try to create some "natural" peaks and valleys in the lights. The great thing about the strips was that they were scraping down on the tree, so they brought out all of the folds and bark of the tree. The $50^{\circ} \mathrm{s}$ would have to be more head on, so the gobos helped to breakup the flatter angle and create depth. I thought that the new look was sufficient in replacing what the strip had accomplished. In a vacuum, the tree did not look as good as it did before. But we do not work in a vacuum, and the overall look of the play was greatly improved by the change.

By the end of our technical rehearsals, I had cut the two things that I had budgeted all of my money for. I was able to return the strip lights for most of a refund, seeing as I had only used them for a week. I had only bought enough dry ice for the tests, so that money would not be used either. I saved the department some 
money, and more importantly learned something about myself. I had matured as lighting designer. I was truly proud of the product that I was putting out on opening night.

The following photos were taken during the photo call for the production. I feel that they are a strong representation of the final product, and of the style of the design.

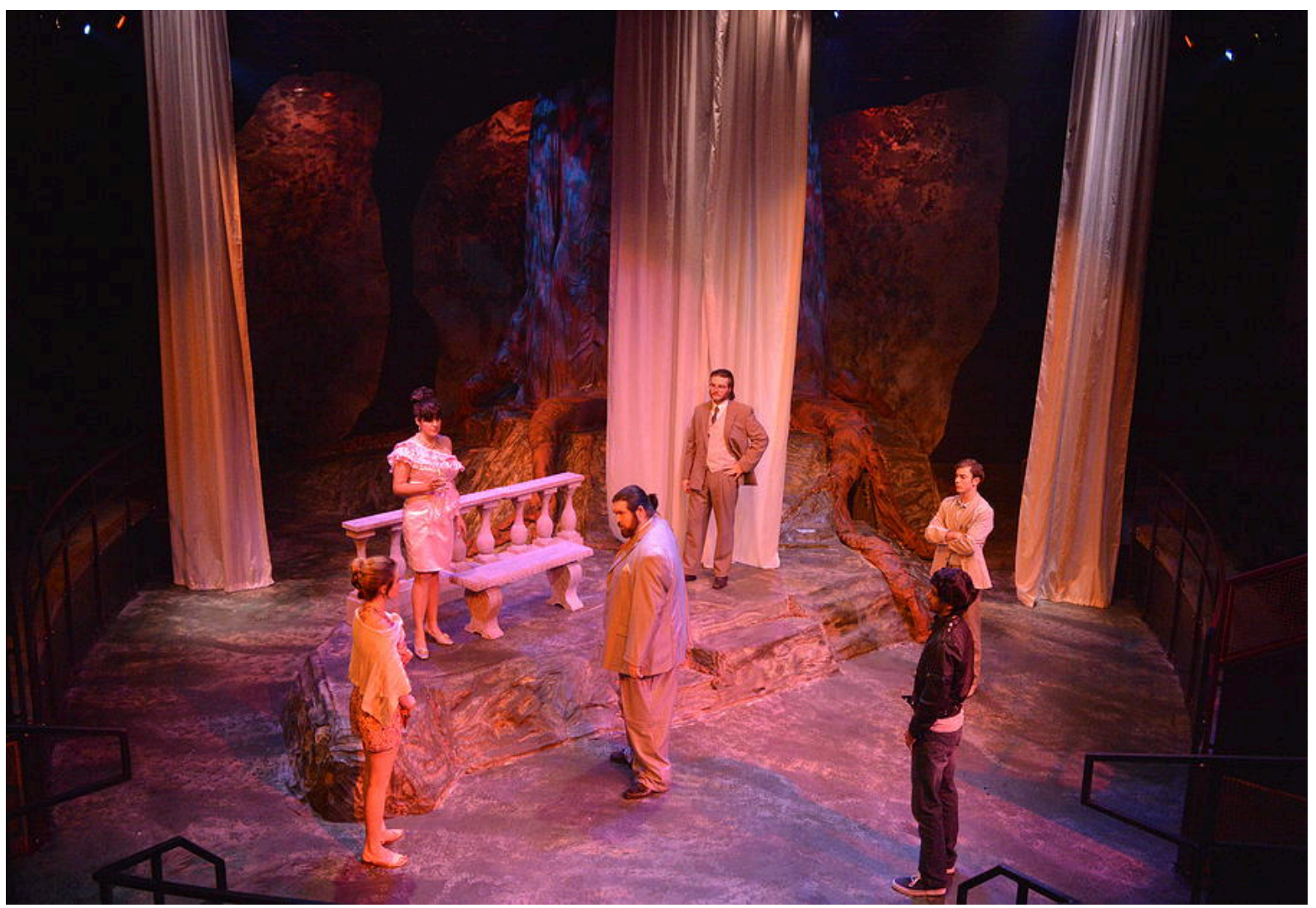

(Figure 16: Act I.I of A Midsummer Night's Dream, "Sunset") 


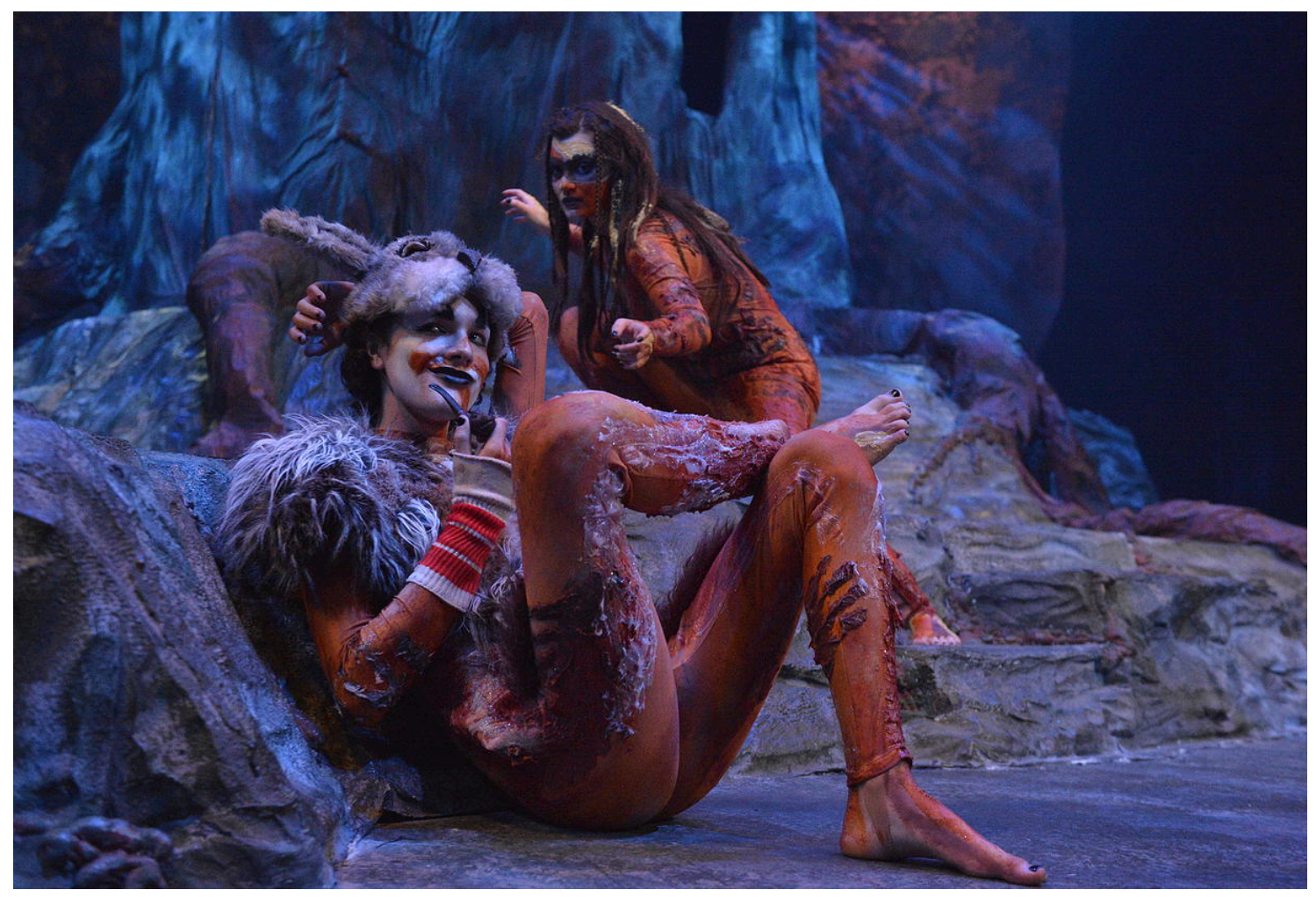

(Figure 17: Act II.I of A Midsummer Night's Dream, "Puck is revealed")

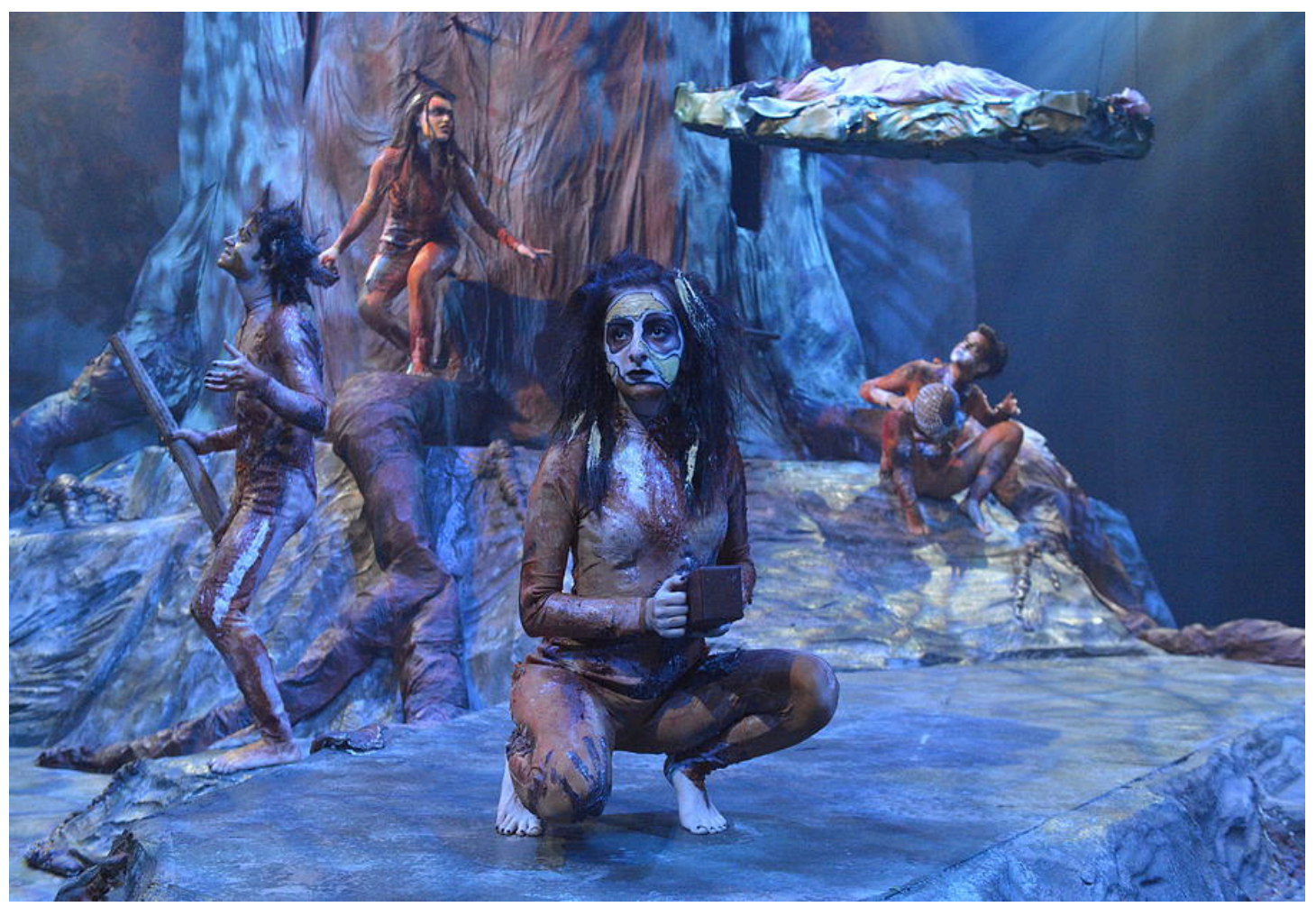

(Figure 18: Act II.II of A Midsummer Night's Dream, "The faeries song") 


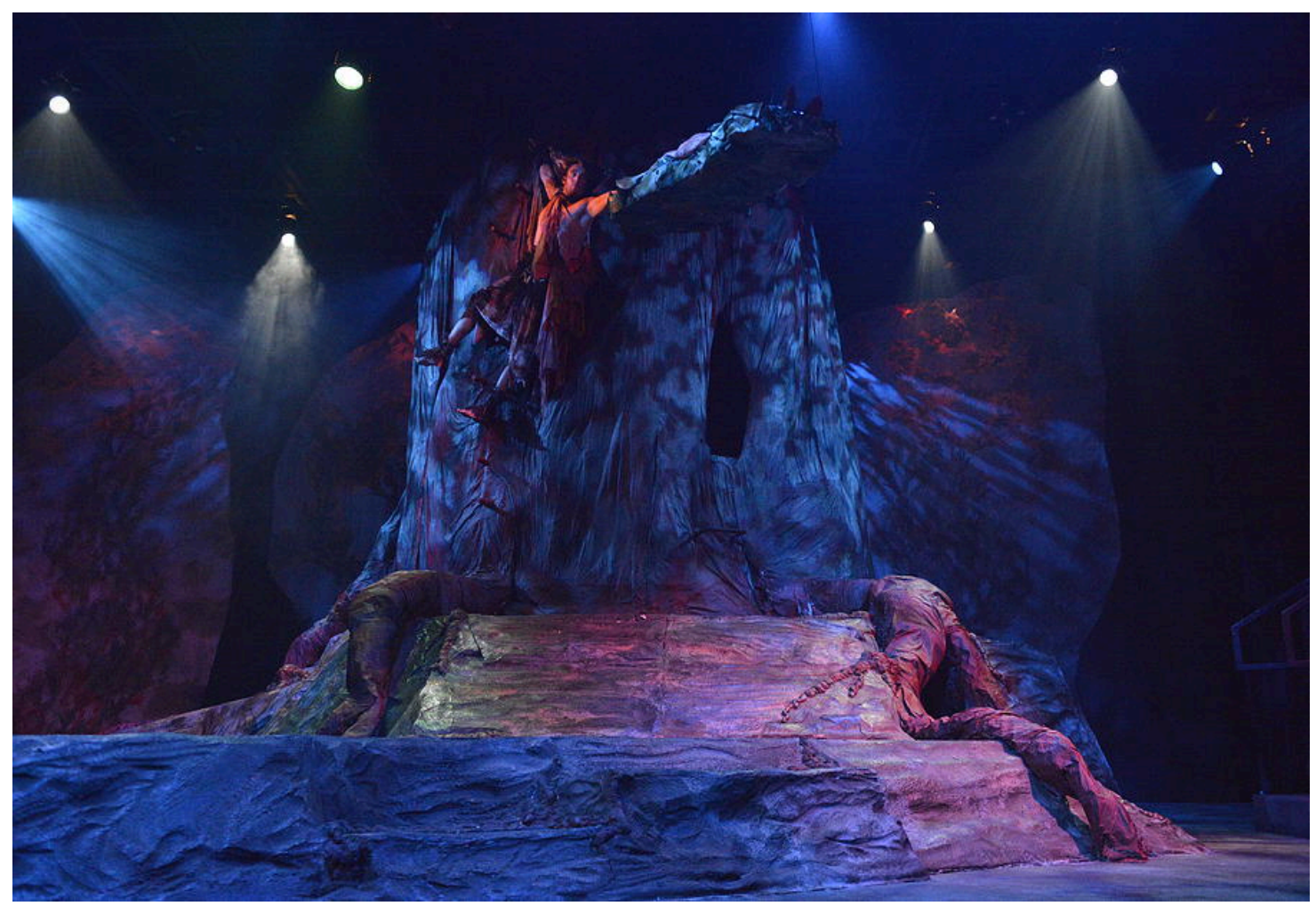

(Figure 19: Act II.II of A Midsummer Night's Dream, “Oberon uses his spell on Titania")

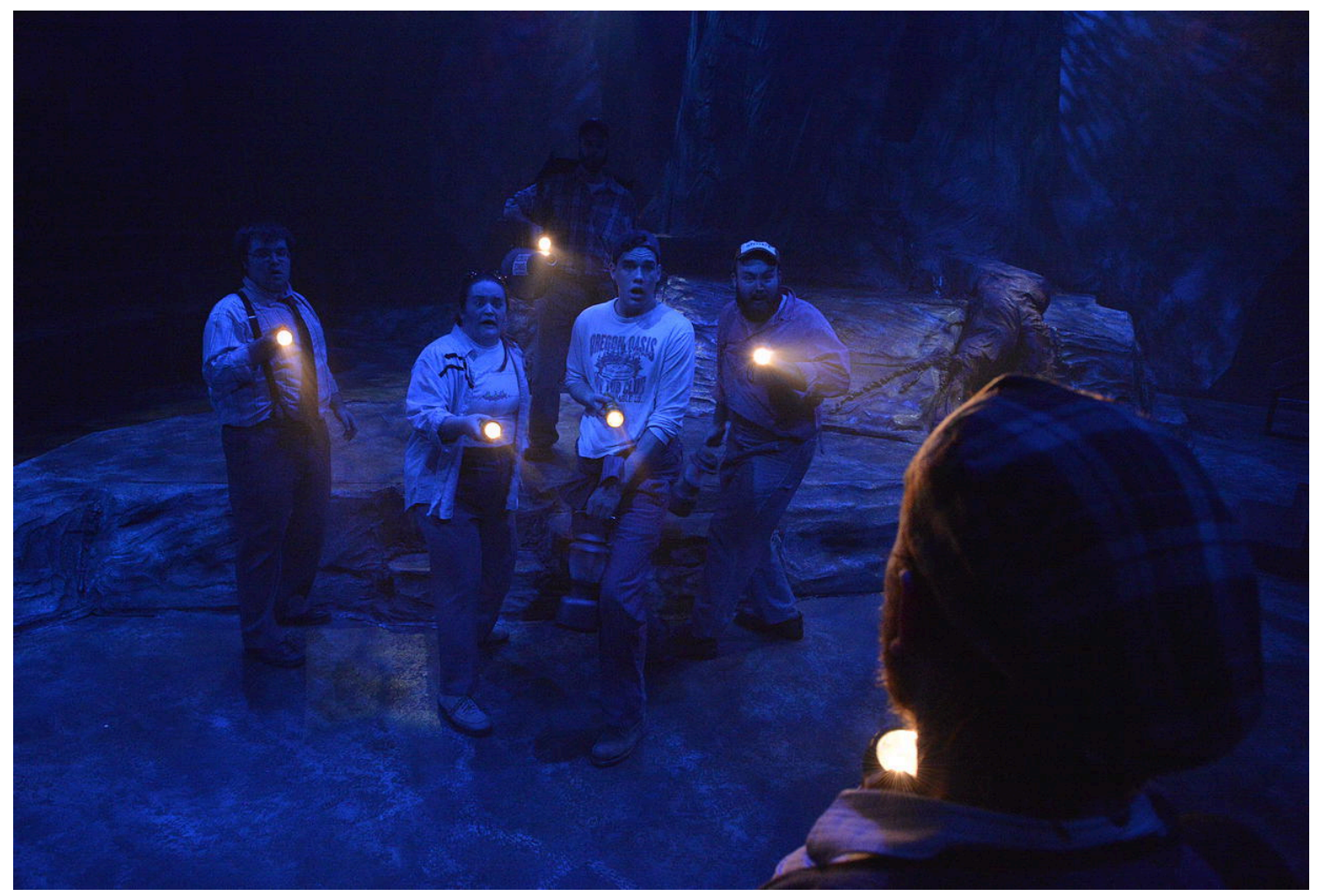

(Figure 20: Act III.I of A Midsummer Night's Dream, "The mechanicals arrive in the forest") 


\section{$\underline{\text { Evaluation }}$}

Self-evaluation has always been a challenging thing for me as an artist. It's not because I find it hard to judge my own work. It's because I find it hard to judge my own work objectively. In the early stages of any project, I usually feel very confident about my work. That's easy to achieve when you're working in a vacuum. In The Empty Space, Peter Brook wrote about the importance of presenting your work, specifically how someone feels watching people react to seeing their work. It is no different then when you think you've stumbled upon a hilarious video, and the first time you go to show it to someone else you realize "this isn't funny at all."

By opening night I have nitpicked every cue so much that I hate everything I've done. That distain only grows when viewing that show towards the end of the run. Fresh eyes breed dissatisfaction. I always thought that was normal. There were always thing I would change if I had two more weeks. I always thought that I was just "staying hungry," but maybe I was just settling for mediocrity. It's one thing to always strive to be better, and it's another to feel like you missed the mark. I have never felt as good about a design on opening night as I did about this show. Something clicked for me as a designer throughout this process. I found my style and, more importantly, I found my process. I found the right tools to help influence my decisions throughout the show, and for that, I am very grateful.

One thing that I used to do as a young designer was design too many unnecessary lights. I would be so nervous about having to change something, that I would design a show using every light that I had available to me. Making sure that 
every inch of the stage could be extremely well lit. What that led to was superfluous lights. Instead of taking the time to carefully decide what the show needed, I wasted precious dimmers on lights I didn't ever use. I could be using those dimmers for lights that enhance the mood of a scene, or give a bit more information about the setting, perhaps adding more texture on stage. Changing this philosophy and spending the time to make strong informed decisions proved fruitful.

The show had some pretty moments. I was genuinely proud of the product I had put out. I had made the right decisions about what to cut, and what things just needed tweaking. My research was strong and I felt that I had done a good job staying true to that. If I could go back and fix one thing, I wish I had done a better job lighting the upstage panels. I didn't get the best coverage out of the instruments that I had chosen, but they were the best option that we had in our inventory. In hindsight, I could have used my budget to purchase lighting instruments that could have given us some more variety and better coverage, but I think I would have had a hard time rationalizing using the budget for something that was such a subtle part of the scenery. I would have loved to see the fog work the way that I envisioned it.

Obviously I would change how I spent my budget, seeing as both of those effects were eventually cut. But not going through the process of choosing to cut those would have also cut down on my growth as a designer. 


\section{Conclusion}

I was recently at a talkback for a production of Mother Courage and Her Children, and the question was asked of the cast "why do you do what you do?" I know why I do what I do. I'm a lighting designer because enjoy story telling. I find light to be a fantastic media for telling a story. Sure, I want to tug at heartstrings, and make people feel emotions without them knowing why, and maybe create an effect that makes people go "ooh." At the end of the day though, what I really aim to do is support the text and the other facets of the design.

At the end of every semester at WVU, we have evaluations with our professors. We present our portfolio for 10 minutes, and then there is a talkback session where we are evaluated on our work from the past semester. Our costume designer, Mary McClung, was in that meeting. Professor McClung gave me the best compliment that I received for my work on A Midsummer Night's Dream. Professor McClung thanked me for helping to tie the scene design and the costume design together. I brought them into the same world. Under work lights, the two seemed a

little disjointed. Professor McClung's words meant, to me, that I had achieved my goal. I didn't just light a set, or light the costumes, or light the actors. I lit $A$ Midsummer Night's Dream. 


\section{Works Cited}

A Midsummer Night's Dream. Pelican Shakespeare, 2000. Print.

The World's Best Photos - Flickr Hive Mind. Web. 27 Sept. 2014.

<http://flickrhivemind.net/>.

Stock Photography, Royalty-Free Photos, Video Footage \& Music / Getty Images. Web. 27 Sept. 2014. <http://www.gettyimages.com/>. 
APPENDICES 
ME: James Brown

\begin{tabular}{|c|c|c|c|c|c|c|}
\hline Channel & Dm Pos & Unit\# & Purpose & Inst Type \& Access \& Watt & Color & Gobo \\
\hline \multirow[t]{2}{*}{ (1) } & 26 & $\mathrm{~F} 7 \mathrm{~b}$ & $A$ & Source 4 36deg $575 w$ & R365 & \\
\hline & 26 & $\mathrm{G} 7 \mathrm{~b}$ & $\mathrm{~B}$ & Source 4 36deg $575 w$ & R365 & \\
\hline \multirow{2}{*}{ (2) } & 34 & $\mathrm{D} 8 \mathrm{~b}$ & $\mathrm{C}$ & Source 4 36deg 575w & R365 & \\
\hline & 34 & G9b & D & Source 4 36deg $575 w$ & R365 & \\
\hline \multirow[t]{2}{*}{ (3) } & 25 & $\mathrm{H} 10 \mathrm{a}$ & $\mathrm{H}$ & Source 4 36deg $575 w$ & R365 & \\
\hline & 25 & $18 \mathrm{~b}$ & $\mathrm{E}$ & Source 4 36deg $575 w$ & R365 & \\
\hline (4) & 76 & $\mathrm{E} 10 \mathrm{~b}$ & $\mathrm{~F}$ & Source 4 36deg $575 \mathrm{w}$ & R365 & \\
\hline (5) & 15 & $\mathrm{G} 12 \mathrm{~b}$ & $G$ & Source 4 36deg $575 w$ & R365 & \\
\hline (6) & 80 & $\mathrm{E} 14 \mathrm{~b}$ & 1 & Source 4 36deg 575w & R365 & \\
\hline (7) & 90 & 114 & $\mathrm{~J}$ & Source 4 36deg 575w & R365 & \\
\hline \multirow[t]{2}{*}{ (11) } & 28 & $\mathrm{~F} 7 \mathrm{a}$ & $A$ & Strand/Century 6x9 750w & R99 & \\
\hline & 28 & $\mathrm{G} 7 \mathrm{a}$ & $\mathrm{B}$ & Strand/Century $6 \times 9750 \mathrm{w}$ & R99 & \\
\hline \multirow[t]{2}{*}{$(12)$} & 36 & D8a & $\mathrm{C}$ & Strand/Century 6x9 750w & R99 & \\
\hline & 36 & G9a & $\mathrm{D}$ & Strand/Century $6 \times 9750 w$ & R99 & \\
\hline \multirow[t]{2}{*}{ (13) } & 39 & $\mathrm{H} 10 \mathrm{~b}$ & $\mathrm{H}$ & Strand/Century 6x9 750w & R99 & \\
\hline & 39 & $18 a$ & $\mathrm{E}$ & Strand/Century $6 \times 9750 \mathrm{w}$ & R99 & \\
\hline (14) & 75 & $\mathrm{E} 10 \mathrm{a}$ & $\mathrm{F}$ & Strand/Century 6x9 750w & R99 & \\
\hline (15) & 16 & G12a & $G$ & Strand/Century 6x9 750w & R99 & \\
\hline \multirow[t]{2}{*}{$(21)$} & 2 & D11 & A & Source 4 36deg $575 \mathrm{w}$ & R365 & \\
\hline & 2 & F12 & B & Source 4 36deg $575 w$ & R365 & \\
\hline \multirow[t]{2}{*}{$(22)$} & 18 & $\mathrm{~B} 12 \mathrm{a}$ & C & Source 4 36deg $575 w$ & R365 & \\
\hline & 18 & D13 & $\mathrm{D}$ & Source 4 36deg $575 w$ & R365 & \\
\hline \multirow[t]{2}{*}{$(23)$} & 30 & $F 14 b$ & $E$ & Source 4 36deg 575w & R365 & \\
\hline & 30 & F16 & $\mathrm{H}$ & Source 436 deg $575 w$ & R365 & \\
\hline (24) & 52 & B15 & $\mathrm{F}$ & Source 4 36deg $575 \mathrm{w}$ & R365 & \\
\hline$(25)$ & 38 & D17 & $G$ & Source 4 36deg $575 w$ & R365 & \\
\hline (26) & 56 & B18 & 1 & Source 4 36deg 575w & R365 & \\
\hline
\end{tabular}




\begin{tabular}{|c|c|c|c|c|c|c|}
\hline Channel & Dm Pos & Unit\# & Purpose & Inst Type \& Access \& Watt & Color & Gobo \\
\hline$(27)$ & 67 & F18 & $\mathrm{J}$ & Source 4 36deg 575w & R365 & \\
\hline \multirow[t]{2}{*}{ (31) } & 85 & $\mathrm{G} 11 \mathrm{~b}$ & $A$ & Source 4 36deg 575w & R365 & \\
\hline & 85 & $\mathrm{I} 11$ & $\mathrm{~B}$ & Source 4 36deg $575 w$ & R365 & \\
\hline \multirow[t]{2}{*}{ (32) } & 91 & $\mathrm{G} 14 \mathrm{~b}$ & C & Source 4 36deg 575w & R365 & \\
\hline & 91 & 113 & $\mathrm{D}$ & Source 4 36deg $575 w$ & R365 & \\
\hline \multirow{2}{*}{ (33) } & 41 & K13 & $E$ & Source 4 36deg $575 w$ & R365 & \\
\hline & 41 & K16 & $\mathrm{H}$ & Source 4 36deg 575w & R365 & \\
\hline (34) & 88 & G16 & $\mathrm{F}$ & Source 4 36deg 575w & R365 & \\
\hline (35) & 96 & 117 & $G$ & Source 4 36deg 575w & R365 & \\
\hline (36) & 95 & $\mathrm{H} 18 \mathrm{a}$ & 1 & Source 4 36deg $575 w$ & R365 & \\
\hline$(37)$ & 55 & K18 & $\mathrm{J}$ & Source 4 36deg 575w & R365 & \\
\hline \multirow[t]{2}{*}{ (41) } & 77 & E14a & $A$ & S4 PAR WFL 575w & R55 & \\
\hline & 77 & G14a & $\mathrm{B}$ & S4 PAR WFL 575w & R55 & \\
\hline \multirow[t]{2}{*}{ (42) } & 12 & $\mathrm{D} 16 \mathrm{~b}$ & C & S4 PAR WFL 575w & R55 & \\
\hline & 12 & $\mathrm{~F} 17 \mathrm{~b}$ & D & S4 PAR WFL 575w & R55 & \\
\hline \multirow[t]{2}{*}{ (43) } & 93 & $\mathrm{H} 19 \mathrm{~b}$ & $\mathrm{H}$ & S4 PAR WFL 575w & R55 & \\
\hline & 93 & I16b & $\mathrm{E}$ & S4 PAR WFL 575w & R55 & \\
\hline \multirow[t]{2}{*}{$(51)$} & 92 & $\mathrm{~F} 14 \mathrm{a}$ & $A$ & S4 PAR WFL 575w & R83 & \\
\hline & 92 & $\mathrm{H} 14$ & $\mathrm{~B}$ & S4 PAR WFL 575w & $\mathrm{R} 83$ & \\
\hline \multirow[t]{2}{*}{$(52)$} & 10 & D16a & $\mathrm{C}$ & S4 PAR WFL 575w & R83 & \\
\hline & 10 & $\mathrm{~F} 17 \mathrm{a}$ & D & S4 PAR WFL 575w & R83 & \\
\hline \multirow[t]{2}{*}{ (53) } & 94 & $\mathrm{H} 19 \mathrm{a}$ & $\mathrm{H}$ & S4 PAR WFL 575w & R83 & \\
\hline & 94 & I16a & $\mathrm{E}$ & S4 PAR WFL 575w & R83 & \\
\hline$(54)$ & 64 & E19 & $\mathrm{F}$ & S4 PAR WFL 575w & R83 & \\
\hline$(55)$ & 68 & $\mathrm{~F} 20$ & $G$ & S4 PAR WFL 575w & R83 & \\
\hline (56) & 62 & E21 & 1 & S4 PAR WFL 575w & R83 & \\
\hline$(57)$ & 13 & $\mathrm{H} 21$ & $\bar{J}$ & S4 PAR WFL 575w & R83 & \\
\hline \multirow[t]{2}{*}{ (61) } & 78 & E13 & Top/ Back & 8" Fres 1kw & A4950 & \\
\hline & 78 & E15 & Top/ Back & 8" Fres $1 \mathrm{kw}$ & A4950 & \\
\hline
\end{tabular}




\begin{tabular}{|c|c|c|c|c|c|c|}
\hline Channel & Dm Pos & Unit\# & Purpose & Inst Type $\&$ Access $\&$ Watt & Color & Gobo \\
\hline \multirow{2}{*}{$(62)$} & 89 & $\mathrm{H} 13$ & Top/ Back & 8" Fres 1kw & A4950 & \\
\hline & 89 & $\mathrm{H} 15$ & Top/ Back & 8" Fres 1kw & A4950 & \\
\hline \multirow[t]{2}{*}{ (63) } & 63 & E17 & Top/ Back & 8" Fres $1 \mathrm{kw}$ & A4950 & \\
\hline & 63 & E20 & Top/ Back & 8" Fres 1kw & A4950 & \\
\hline \multirow[t]{2}{*}{$(64)$} & 1 & $\mathrm{H} 17$ & Top/ Back & 8" Fres 1kw & A4950 & \\
\hline & 1 & $\mathrm{H} 20$ & Top/ Back & 8" Fres $1 \mathrm{kw}$ & A4950 & \\
\hline \multirow[t]{2}{*}{ (71) } & 42 & $\mathrm{~B} 7 \mathrm{a}$ & Cross & Source 4 36deg 575w & $R 3220$ & \\
\hline & 42 & B11a & Cross & Source 4 36deg $575 w$ & R3220 & \\
\hline \multirow[t]{2}{*}{$(72)$} & 73 & $\mathrm{E} 12 \mathrm{a}$ & Cross & Source 4 36deg 575w & R3220 & \\
\hline & 73 & G10a & Cross & Source 4 36deg 575w & R3220 & \\
\hline$(73)$ & 46 & B14a & Cross & Source 4 36deg 575w & R3220 & \\
\hline$(74)$ & 84 & E16a & Cross & Source 4 36deg 575w & R3220 & \\
\hline \multirow[t]{2}{*}{$(75)$} & 20 & $B 7 b$ & Cross & Strand/Century 6x9 750w & R4660 & \\
\hline & 20 & B11b & Cross & Strand/Century $6 \times 9750 w$ & R4660 & \\
\hline \multirow[t]{2}{*}{$(76)$} & 4 & $\mathrm{E} 12 \mathrm{~b}$ & Cross & Strand/Century 6x9 750w & R4660 & \\
\hline & 4 & $\mathrm{H} 11$ & Cross & Strand/Century $6 \times 9750 w$ & R4660 & \\
\hline$(77)$ & 48 & B14b & Cross & Strand/Century 6x9 750w & R4660 & \\
\hline$(78)$ & 79 & E16b & Cross & Strand/Century 6x9 750w & R4660 & \\
\hline \multirow[t]{2}{*}{ (81) } & 3 & F10b & Cross & Source 4 36deg yellow $575 w$ & L161 & \\
\hline & 3 & $\mathrm{H} 12 \mathrm{a}$ & Cross & Source 4 36deg yellow $575 w$ & L161 & \\
\hline \multirow[t]{2}{*}{$(82)$} & 17 & $\mathrm{~K} 7 \mathrm{a}$ & Cross & Source 4 36deg yellow $575 w$ & L161 & \\
\hline & 17 & $\mathrm{~K} 11 \mathrm{a}$ & Cross & Source 4 36deg yellow $575 w$ & L161 & \\
\hline$(83)$ & 9 & $\mathrm{H} 16 \mathrm{a}$ & Cross & Source 4 36deg yellow $575 w$ & L161 & \\
\hline$(84)$ & 49 & $\mathrm{~K} 14 \mathrm{a}$ & Cross & Source 4 36deg yellow 575w & L161 & \\
\hline \multirow[t]{2}{*}{$(85)$} & 6 & E11 & Cross & Strand/Century 6x9 750w & R58 & \\
\hline & 6 & $\mathrm{H} 12 \mathrm{~b}$ & Cross & Strand/Century 6x9 750w & R58 & \\
\hline \multirow[t]{2}{*}{$(86)$} & $\begin{array}{l}19 \\
\ldots .\end{array}$ & K7b & Cross & $\begin{array}{c}\text { Strand/Century 6x9 750w } \\
\ldots \ldots \ldots \ldots \ldots \ldots \ldots \ldots \ldots \ldots \ldots \ldots \ldots\end{array}$ & R58 & \\
\hline & 19 & $\mathrm{~K} 11 \mathrm{~b}$ & Cross & Strand/Century 6x9 750w & R58 & \\
\hline$(87)$ & 7 & $\mathrm{H} 16 \mathrm{~b}$ & Cross & Strand/Century 6x9 750w & R58 & \\
\hline
\end{tabular}




\begin{tabular}{|c|c|c|c|c|c|c|}
\hline Channel & Dm Pos & Unit\# & Purpose & Inst Type \& Access \& Watt & Color & Gobo \\
\hline (88) & 51 & $\mathrm{~K} 14 \mathrm{~b}$ & Cross & Strand/Century 6x9 750w & R58 & \\
\hline \multirow[t]{2}{*}{ (91) } & 44 & B8 & Cross Text & Source 4 36deg yellow $575 w$ & $\mathrm{R} 74$ & \\
\hline & 44 & B10 & Cross Text & Source 4 36deg yellow $575 w$ & $R 74$ & \\
\hline \multirow[t]{2}{*}{ (92) } & 8 & F9 & Cross Text & Source 4 36deg yellow $575 w$ & R74 & \\
\hline & 8 & G10b & Cross Text & Source 436 deg $575 w$ & R74 & \\
\hline (93) & 14 & C13 & Cross Text & Source 4 36deg yellow $575 w$ & R74 & \\
\hline \multirow[t]{2}{*}{ (94) } & 5 & F15 & Cross Text & Source 4 36deg yellow $575 w$ & R74 & \\
\hline & 5 & $\mathrm{H} 18 \mathrm{~b}$ & Cross Text & Source 4 36deg yellow $575 w$ & R74 & \\
\hline \multirow[t]{2}{*}{ (95) } & 74 & F10a & Cross Text & Source 4 36deg yellow $575 w$ & R74 & \\
\hline & 74 & G11a & Cross Text & Source 4 36deg yellow $575 w$ & R74 & \\
\hline \multirow[t]{2}{*}{ (96) } & 45 & K8a & Cross Text & Source 4 36deg yellow $575 w$ & R74 & \\
\hline & 45 & K10 & Cross Text & Source 4 36deg yellow $575 w$ & R74 & \\
\hline \multirow[t]{2}{*}{ (97) } & 61 & E18 & Cross Text & Source 4 36deg yellow $575 w$ & R74 & \\
\hline & 61 & G15 & Cross Text & Source 4 36deg yellow $575 w$ & R74 & \\
\hline (98) & 11 & J13 & Cross Text & Source 4 36deg 575w & R74 & \\
\hline \multirow[t]{2}{*}{ (101) } & 58 & A20 & Tree Gobo & Source 4 50deg 575w & R80 & \\
\hline & 58 & B22 & Tree Gobo & Source 4 50deg $575 w$ & $\mathrm{R} 80$ & \\
\hline \multirow[t]{2}{*}{$(102)$} & 57 & K22 & Tree Gobo & Source 4 50deg 575w & $\mathrm{R} 80$ & \\
\hline & 57 & L20 & Tree Gobo & Source 4 50deg 575w & $R 80$ & \\
\hline \multirow[t]{2}{*}{$(104)$} & 43 & B19 & Tree Gobo & Source 4 50deg 575w & $\mathrm{R} 22$ & \\
\hline & 43 & K19 & Tree Gobo & Source 4 50deg $575 w$ & $\mathrm{R} 22$ & \\
\hline \multirow[t]{2}{*}{$(112)$} & 40 & D23 & Branches & Source 4 50deg 575w & $\mathrm{R} 80$ & \\
\hline & 40 & 123 & Branches & Source 4 50deg 575w & R80 & \\
\hline (113) & 21 & $\mathrm{C} 20$ & Branches & Source 4 50deg 575w & $\mathrm{R} 80$ & \\
\hline (114) & 21 & $\mathrm{~J} 20$ & Branches & Source 4 50deg 575w & R80 & \\
\hline (115) & 40 & C16 & Branches & Source 4 50deg 575w & $\mathrm{R} 80$ & \\
\hline (116) & 35 & J16 & Branches & Source 4 50deg 575w & R80 & \\
\hline$(117)$ & 81 & D21 & Branches & Source 4 50deg 575w & NC & \\
\hline (118) & 81 & 121 & Branches & Source 4 50deg 575w & NC & \\
\hline
\end{tabular}




\begin{tabular}{|c|c|c|c|c|c|c|}
\hline Channel & Dm Pos & Unit\# & Purpose & Inst Type $\&$ Access $\&$ Watt & Color & Gobo \\
\hline \multirow{3}{*}{$(121)$} & 27 & CENTER & & Altman Zip Strip Cell 750w & R127 & \\
\hline & 27 & SL & & Altman Zip Strip Cell 750w & R127 & \\
\hline & 27 & $\mathrm{SR}$ & & Altman Zip Strip Cell 750w & $\mathrm{R} 127$ & \\
\hline \multirow[t]{3}{*}{$(122)$} & 31 & CENTER & & Altman Zip Strip Cell 750w & R125 & \\
\hline & 31 & SL & & Altman Zip Strip Cell 750w & R125 & \\
\hline & 31 & SR & & Altman Zip Strip Cell 750w & $\mathrm{R} 125$ & \\
\hline \multirow{3}{*}{ (123) } & 32 & CENTER & & Altman Zip Strip Cell 750w & R89+R114 & \\
\hline & 32 & SL & & Altman Zip Strip Cell 750w & $\mathrm{R} 89+\mathrm{R} 114$ & \\
\hline & 32 & SR & & Altman Zip Strip Cell 750w & $\mathrm{R} 89+\mathrm{R} 114$ & \\
\hline \multirow{2}{*}{ (151) } & 60 & $\mathrm{C} 24$ & US Panel & 3 Cell Sky Cyc Center 1kw & $\mathrm{R} 127$ & \\
\hline & 60 & 124 & US Panel & 3 Cell Sky Cyc Center $1 \mathrm{kw}$ & $\mathrm{R} 127$ & \\
\hline$(152)$ & 83 & F24 & US Panel & 3 Cell Sky Cyc Center 1kw & $\mathrm{R} 127$ & \\
\hline \multirow{2}{*}{ (161) } & 59 & D24 & US Panel & 3 Cell Sky Cyc Center 1 kw & R76 & \\
\hline & 59 & $\mathrm{~J} 24$ & US Panel & 3 Cell Sky Cyc Center $1 \mathrm{kw}$ & R76 & \\
\hline$(162)$ & 82 & G24 & US Panel & 3 Cell Sky Cyc Center 1kw & $R 76$ & \\
\hline$(201)$ & 87 & G18 & Bower Rotator & Source 4 36deg $575 w$ & NC & \\
\hline \multirow[t]{2}{*}{$(211)$} & 39 & $\mathrm{H} 4$ & Sunset Cross & Alt 360Q 6x12 750w & $\mathrm{R} 22$ & \\
\hline & 39 & J5 & Sunset Cross & Alt $360 \mathrm{Q} 6 \times 12750 w$ & $\mathrm{R} 22$ & \\
\hline \multirow[t]{3}{*}{$(212)$} & 47 & K8b & Sunset Cross & Alt 360Q 6x12 750w & $\mathrm{R} 22$ & \\
\hline & 47 & L9b & Sunset Cross & Alt 360Q 6x12 750w & $\mathrm{R} 22$ & \\
\hline & 47 & $\mathrm{~L} 12$ & Sunset Cross & Alt 360Q 6x12 750w & $\mathrm{R} 22$ & \\
\hline \multirow{2}{*}{ (221) } & 22 & $\mathrm{C} 4$ & Audience Text & Source 4 36deg yellow $575 w$ & R74 & \\
\hline & 22 & C6 & Audience Text & Source 4 36deg yellow $575 w$ & $\mathrm{R} 74$ & \\
\hline \multirow[t]{2}{*}{$(222)$} & 54 & A8 & Audience Text & Source 4 36deg yellow $575 w$ & $R 74$ & \\
\hline & 54 & A9 & Audience Text & Source 4 36deg yellow $575 w$ & R74 & \\
\hline \multirow[t]{2}{*}{ (223) } & 53 & L8 & Audience Text & Source 4 36deg yellow $575 w$ & R74 & \\
\hline & 53 & L9a & Audience Text & Source 4 36deg yellow $575 w$ & $\mathrm{R} 74$ & \\
\hline \multirow[t]{2}{*}{$(224)$} & 37 & $\mathrm{~J} 4$ & Audience Text & Source 4 36deg yellow $575 w$ & $\mathrm{R} 74$ & \\
\hline & 37 & J6 & Audience Text & Source 4 36deg yellow $575 w$ & R74 & \\
\hline
\end{tabular}




\begin{tabular}{|c|c|c|c|c|c|c|}
\hline Channel & Dm Pos & Unit\# & Purpose & Inst Type \& Access \& Watt & Color & Gobo \\
\hline \multirow{2}{*}{ (261) } & 33 & E24 & Tree Back & Selcon Pacific 45-75 750w & NC & \\
\hline & 33 & $\mathrm{H} 24$ & Tree Back & Selecon Pacific $90^{\circ} 750 w$ & NC & \\
\hline$(300)$ & 50 & E4 & Interpreter & Alt 360Q 6x12 750w & $\mathrm{NC}$ & \\
\hline$(301)$ & & & & VL-1000 Tungsten dimmer $1 \mathrm{kw}$ & & \\
\hline$(302)$ & & & & Stage Zoom $12001.2 \mathrm{kw}$ & & \\
\hline$(303)$ & & & & Stage Zoom $12001.2 \mathrm{kw}$ & & \\
\hline \multirow[t]{2}{*}{$(401)$} & & BR1 & DS Panels & PAR MR-16 Birdie 100w & NC & \\
\hline & & BR2 & DS Panels & PAR MR-16 Birdie 100w & NC & \\
\hline \multirow{2}{*}{$(402)$} & & BR3 & DS Panels & PAR MR-16 Birdie 100w & NC & \\
\hline & & BR4 & DS Panels & PAR MR-16 Birdie 100w & NC & \\
\hline \multirow[t]{2}{*}{$(403)$} & & BR5 & DS Panels & PAR MR-16 Birdie 100w & $\mathrm{NC}$ & \\
\hline & & BR6 & DS Panels & PAR MR-16 Birdie 100w & NC & \\
\hline \multirow[t]{2}{*}{$(404)$} & & BR7 & DS Panels & PAR MR-16 Birdie 100w & $\mathrm{NC}$ & \\
\hline & & BR8 & DS Panels & PAR MR-16 Birdie 100w & NC & \\
\hline
\end{tabular}




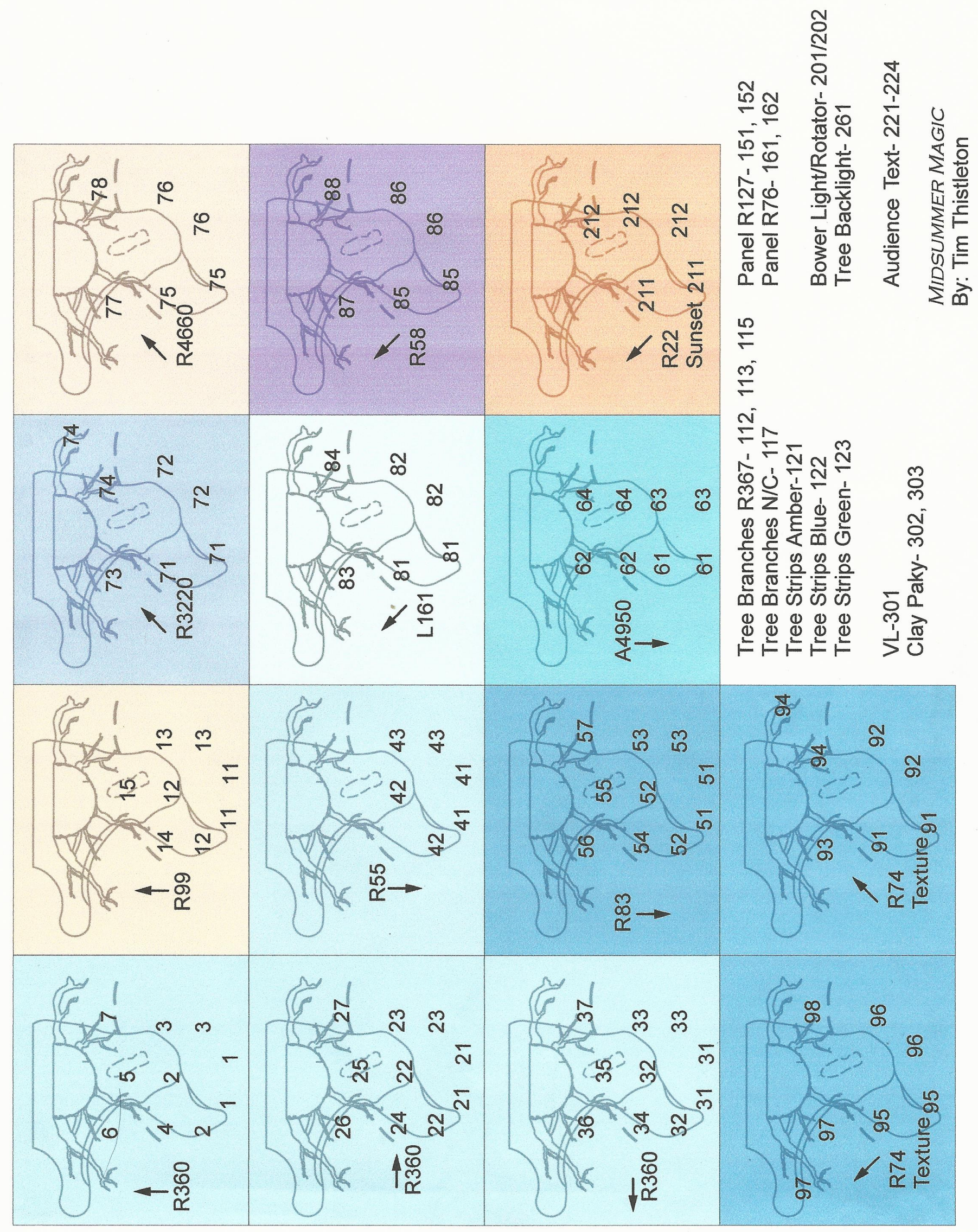




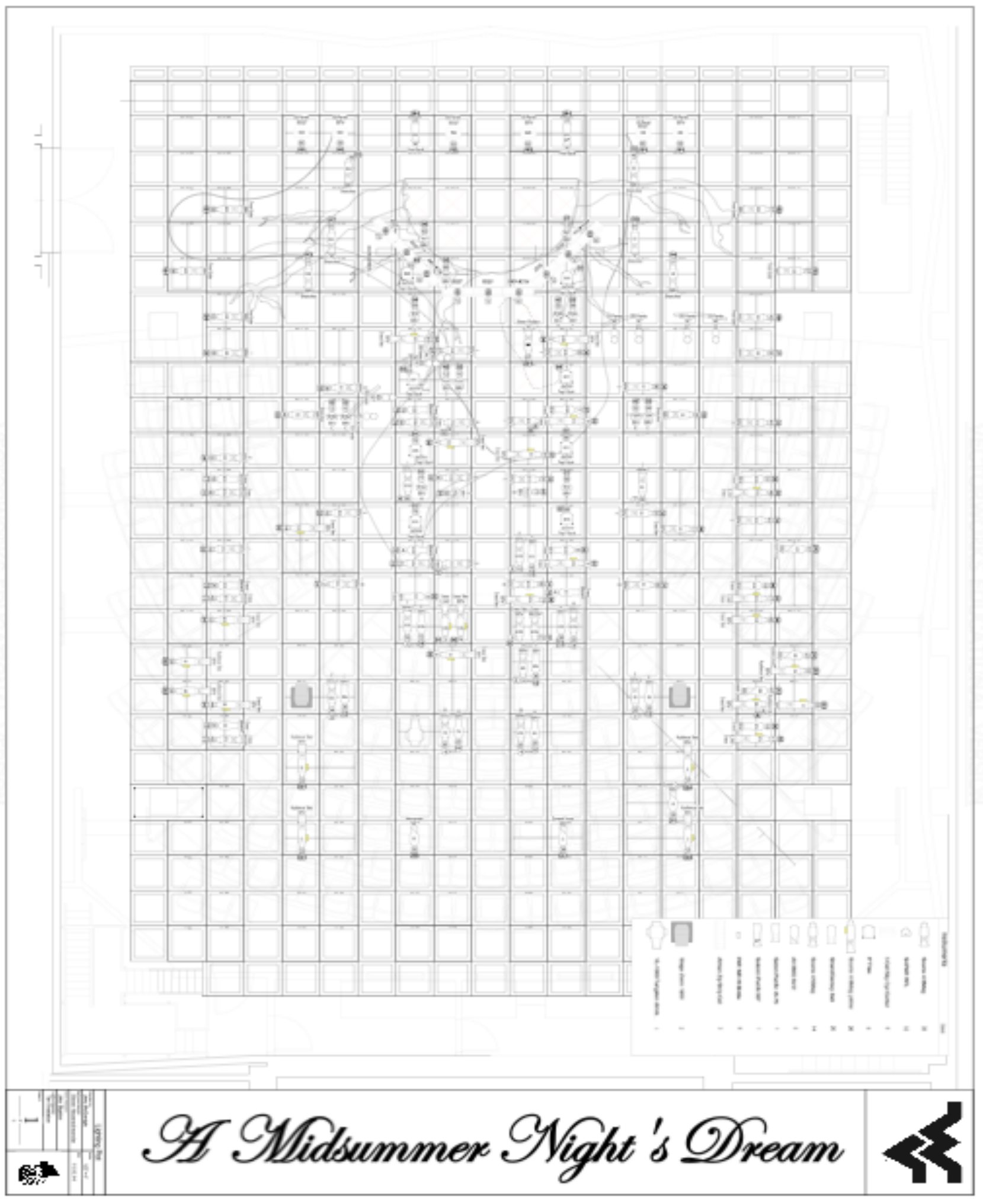

(Larger plot located with supplemental materials) 
Cue List

\begin{tabular}{|c|c|c|}
\hline Cue\# & Time & Purpose \\
\hline 1 & Before house opens & preshow \\
\hline 2 & After house open & Starts 30 min. sunset \\
\hline 5 & house to half & \\
\hline 9 & house out & \\
\hline 101 & Pa 3 Ton of I 1 & Crocs and Teyture \\
\hline 15 & Theseus entrance & Add front light \\
\hline 20 & Pg. 3 "Go Philostrate" & Build light \\
\hline 25 & Pg. 4 "Happy be Theseus" & More light DL \\
\hline 30 & Pg. 12 After Lysander exits & Isolate Helena on bench \\
\hline 35 & Pg. 12/Helena exits/ Top of I. 2 & Transition into Quince's \\
\hline 40 & Pg. 16/Mechanicals exit/ Top of II.1 & Dim forest \\
\hline Haze & With lights 40 & Start the hazer \\
\hline 45 & Pg. 19 "and here my mistress" & Add front light for scene \\
\hline 50 & pg. 24 Puck exits & Isolate Oberon DS \\
\hline 55 & Pg. 24 "I am invisible" & scene lights \\
\hline 60 & Pg. 26 Helena exit & Restore to Oberon/ Titania light \\
\hline 65 & Pg. 27/Puck exit/ Top of II.2 & New part of forest \\
\hline 70 & With placement of Bower & Slowly adds bower special \\
\hline 75 & Pg. 28 with Bower flying & Slow rotation and lights change \\
\hline 80 & Pg. 28 fairies exit & First magic look \\
\hline 85 & Pg. 29 Lysander entrance & scene light \\
\hline 90 & Pg. 30 lovers fall asleep & Lights dim \\
\hline 95 & Pg. 32 Lysander awakes & adds magic \\
\hline 100 & Pg. 33 Lysander exits & slow into no magic \\
\hline 105 & Pg. 34/Top of III.1 & fronts out, slight lantern front \\
\hline 110 & Pg. 37 Puck and Bottom enter & Adds magic \\
\hline 115 & Pg. 37 Mechanicals run & Lantern lights out \\
\hline 120 & Pg. 38 with bower coming in & Bower special and lights change \\
\hline 125 & Pg. 40 with fairy entrances & Fairy lights \\
\hline 130 & Pg. 41 Everyone exits & Fade to just texture \\
\hline 132 & Intermission & House lights \\
\hline 135 & House to half & \\
\hline 139 & House out & \\
\hline & & \\
\hline 140 & Pg. 41/Top of III. 2 & Forest lights \\
\hline 145 & Pg. 41 Oberon to stage & Adds front light \\
\hline 150 & Pg. 43 Demetrius entrance & Adds a little more front \\
\hline 155 & Pg. 45 Demetrius sleeps & fronts dim \\
\hline 160 & Pg. 46 Oberon squeezes herb & Adds magic \\
\hline 165 & Pg. 46 Lysander entrance & More magic \\
\hline 170 & Pg. 47 Demetrius awakes & More magic \\
\hline 175 & Pg. 55 Guys exit & Less magic \\
\hline 180 & Pg. 56 Hermia exit/ Oberon DS & Pre fog look \\
\hline Dry Ice & Pg. 56 "Thou seest these" & Starts fog from tree \\
\hline 185 & Pg. 57 Oberon exits & Front lights out \\
\hline Haze & Pg. 61 Puck exits & Hazer off \\
\hline
\end{tabular}




\section{Cue List}

\begin{tabular}{|l|l|l|}
\hline Cue \# & Time & Purpose \\
\hline & & \\
\hline 190 & Pg. 61/Top of IV.1 & Forest shift, specific area \\
\hline 195 & $\mathrm{Pg} .63$ They sleep & Less front \\
\hline 200 & $\mathrm{Pg} .63$ Oberon squeezes herb & Less magic \\
\hline 205 & $\mathrm{Pg} .64$ Removes head & Starts crisp morning fade \\
\hline 210 & $\mathrm{Pg} .69$ Lovers exit & Slowly brighter \\
\hline 215 & $\mathrm{Pg} .69$ Bottom exit/Top of IV.2 & Transition to Quince's/ Night \\
\hline 220 & $\mathrm{Pg} .71$ All exit/ Top of V.1 & Transition to palace/ Night, warm front \\
\hline 225 & $\mathrm{Pg} .76$ "Let him Approach" & Brighter on "stage" area \\
\hline 230 & $\mathrm{Pg} .86$ With music and dance & Dance light \\
\hline 235 & $\mathrm{Pg} .86$ After dance & Restore to scene light \\
\hline 240 & $\mathrm{Pg} .86$ Puck enters & Isolate and simplify \\
\hline 245 & $\mathrm{Pg} .87$ Oberon enters & Forest with "candlelight" \\
\hline 250 & $\mathrm{Pg} .88$ Fairies exit & Isolate Puck \\
\hline 255 & $\mathrm{Pg} .88$ Isaac blows out candle & Lights out except texture \\
\hline & & \\
\hline 260 & Bows & \\
\hline 265 & After bows & House up and restore stage \\
\hline
\end{tabular}




\begin{tabular}{|l|r|l|}
\hline Type & Quantity & Notes \\
\hline ETC S4 19 degree & 5 & \\
\hline ETC S4 26 degree & 8 & \\
\hline ETC S4 ERS 36 degree (Blue) & 35 & Brighter than yellow \\
\hline ETC S4 ERS 36 degree (Yellow) & 29 & questionable beam quality \\
\hline ETC S4 50 degree & 18 & \\
\hline & 28 & 2 w/o caps \\
\hline Strand/Century 6x9 & 11 & 1 w/ bad cap \\
\hline Strand/Century 6x12 & & \\
\hline & 1 & \\
\hline Selecon zoom & 1 & \\
\hline Selecon 90 & & \\
\hline & 2 & \\
\hline 3 1/2" ERS & & \\
\hline & 5 & \\
\hline Berkley Colortran 40 degree & & \\
\hline & 31 & mixture of Altman and ETC \\
\hline 6" Fresnel & 8 & \\
\hline $8 "$ Fresnel & & \\
\hline & 24 & \\
\hline S4 PAR & & \\
\hline & 15 & \\
\hline PAR 64 & 4 & \\
\hline PAR 56 & 1 & \\
\hline PAR 38 & 10 & Located in Light Cage \\
\hline Birdies & 11 & Located in CAD Lab \\
\hline & 10 & \\
\hline LE Single Cell Broad Cyc lights & 10 & \\
\hline
\end{tabular}

\section{General Notes:}




\section{Additional Research Images}
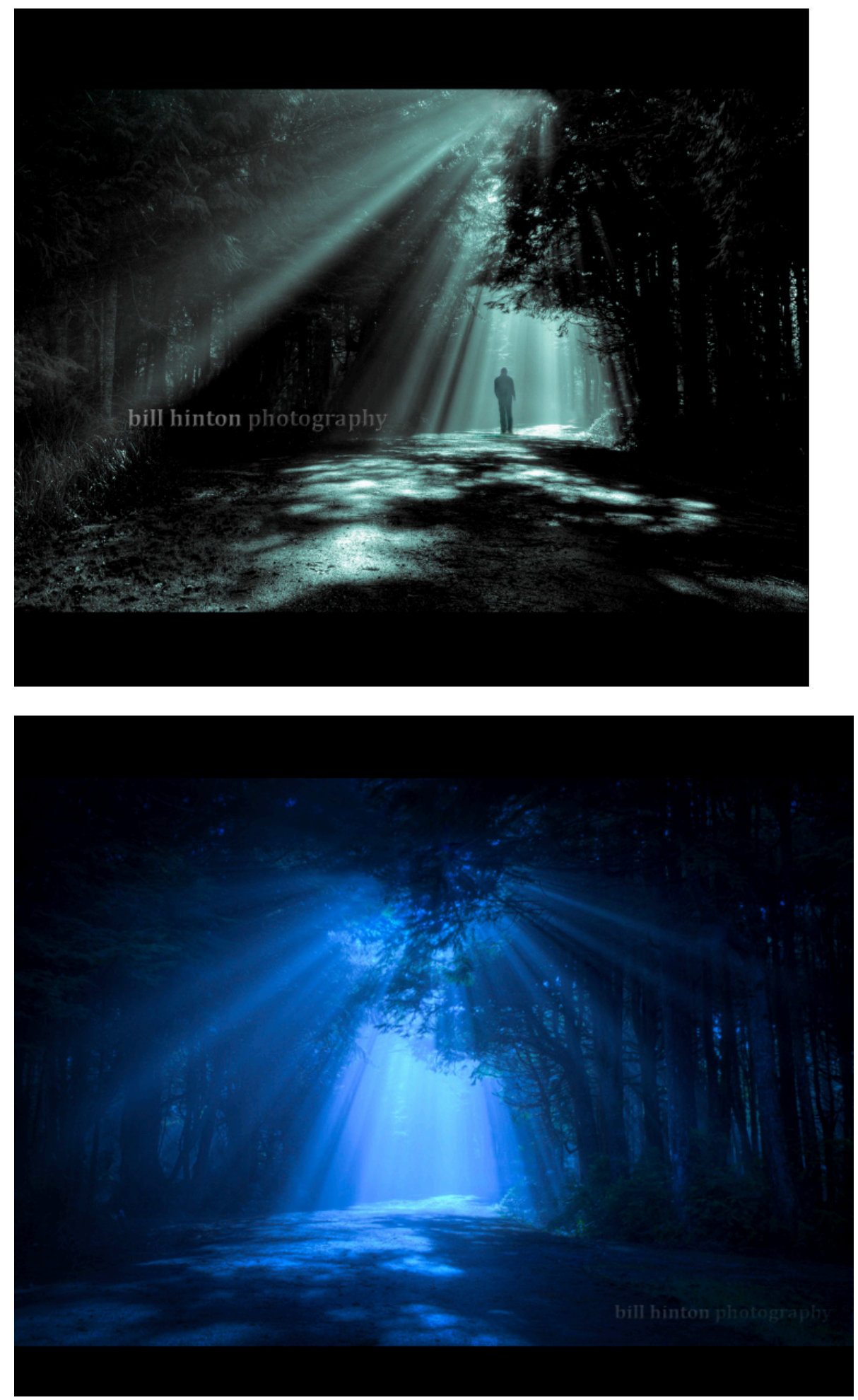

(Forest texture research photos courtesy of Flickr) 

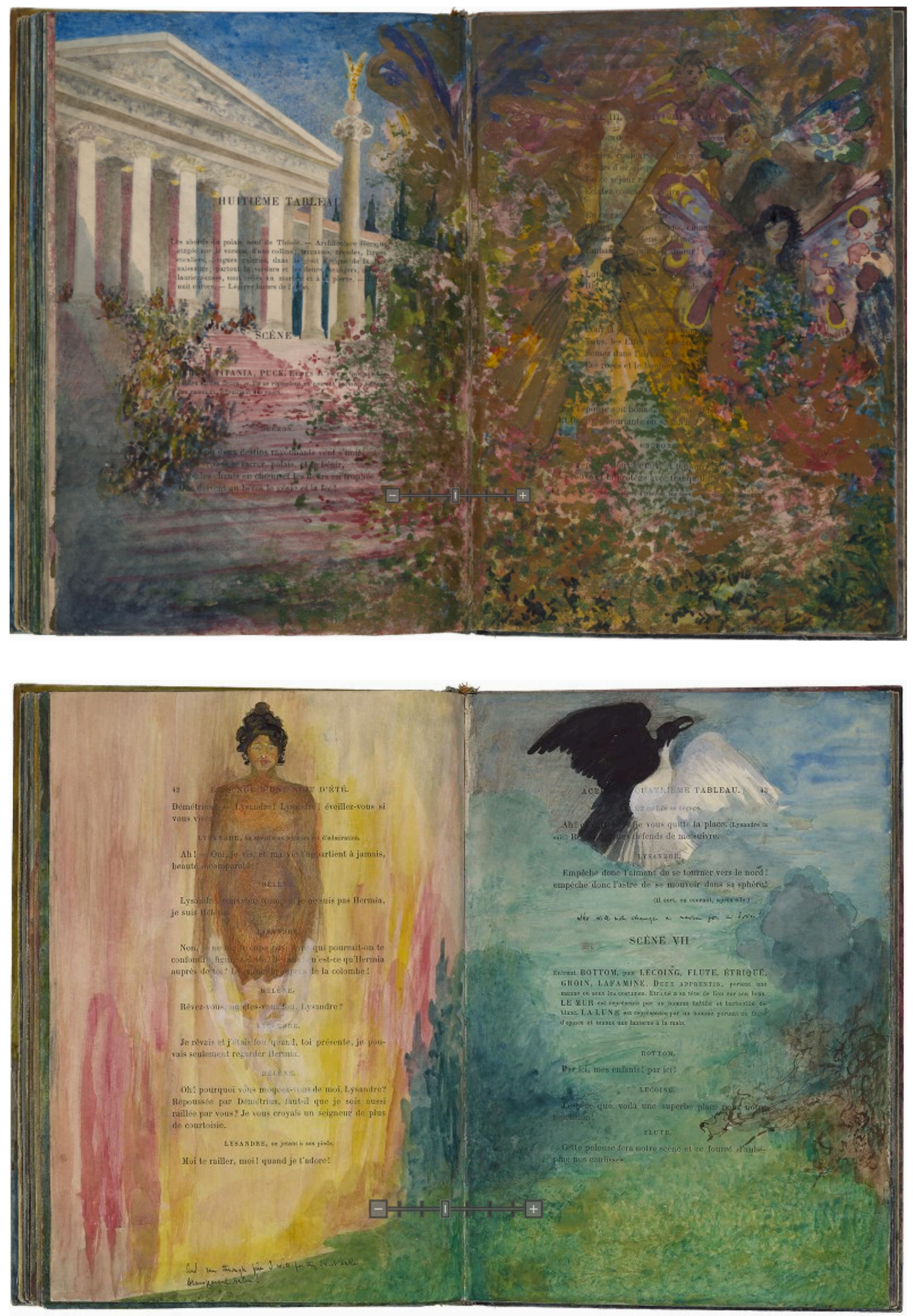

(Watercolor paintings done by Pickney Marcius-Simons, courtesy of The Folger Museum) 


\section{Additional Production Photos}

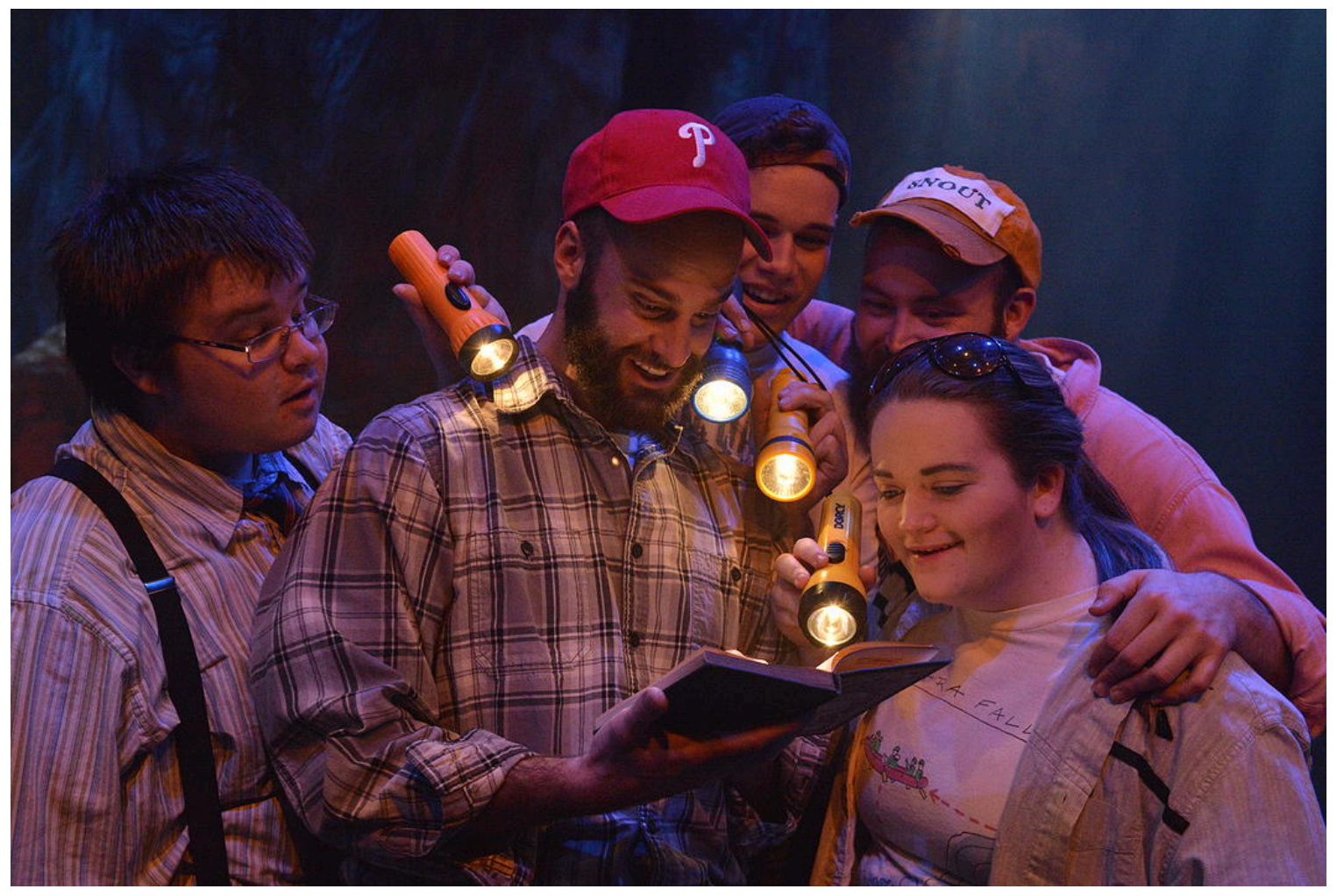

(Act III.I of A Midsummer Night's Dream, "The mechanicals checking the almanac") 


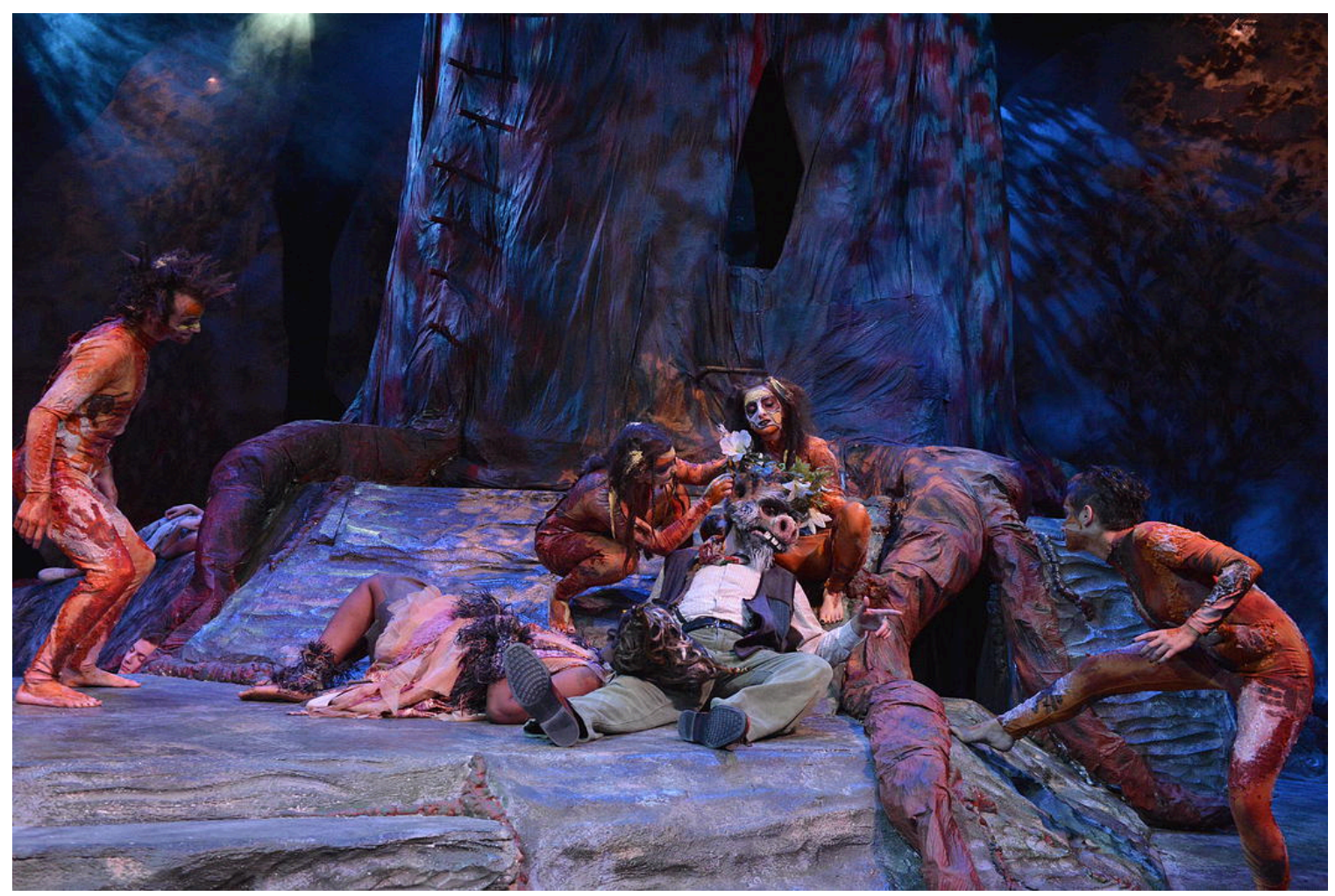

(Act IV.I of A Midsummer Night's Dream, "The fairies pampering Bottom")

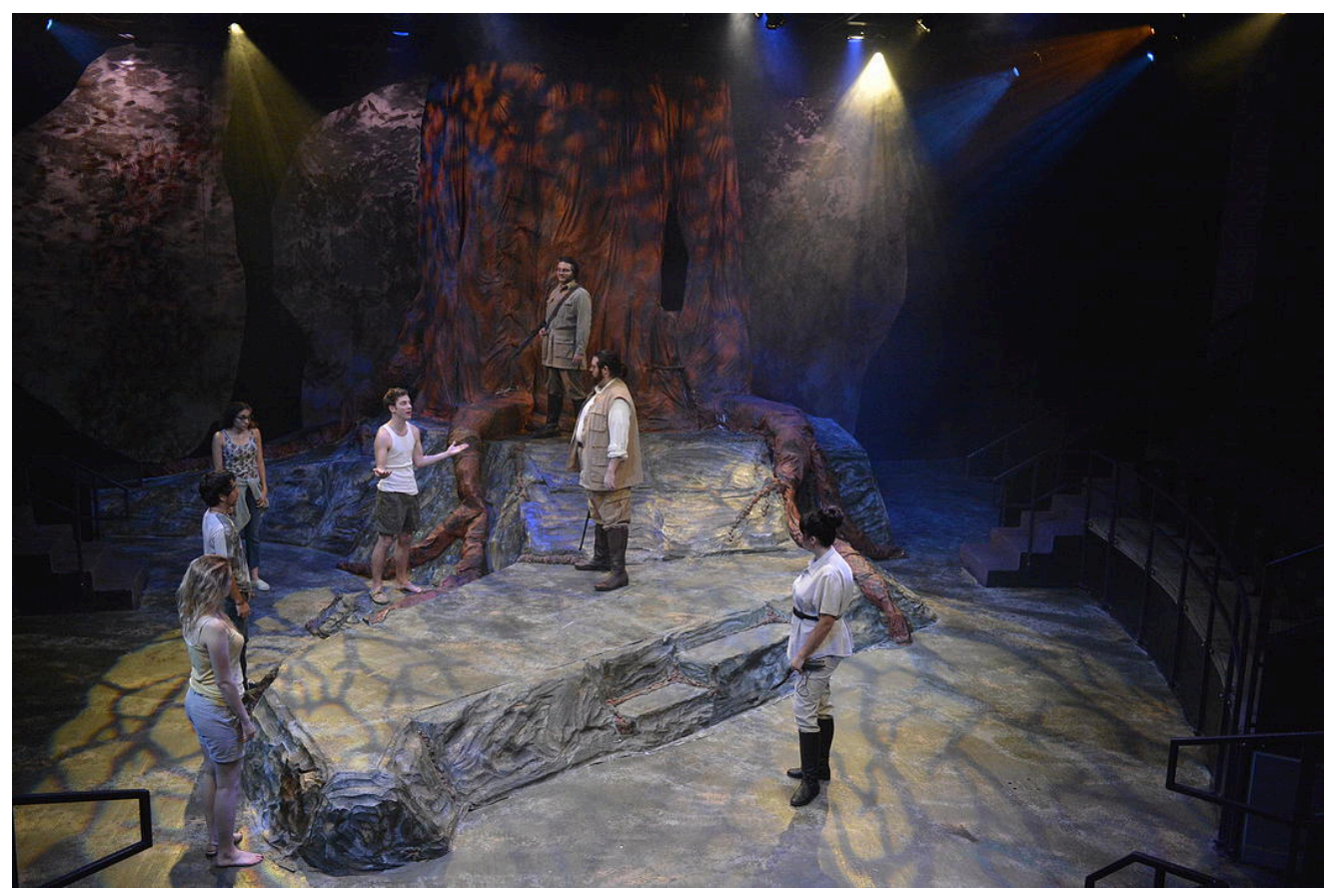

(Act IV.I of A Midsummer Night's Dream, "The lovers are found") 


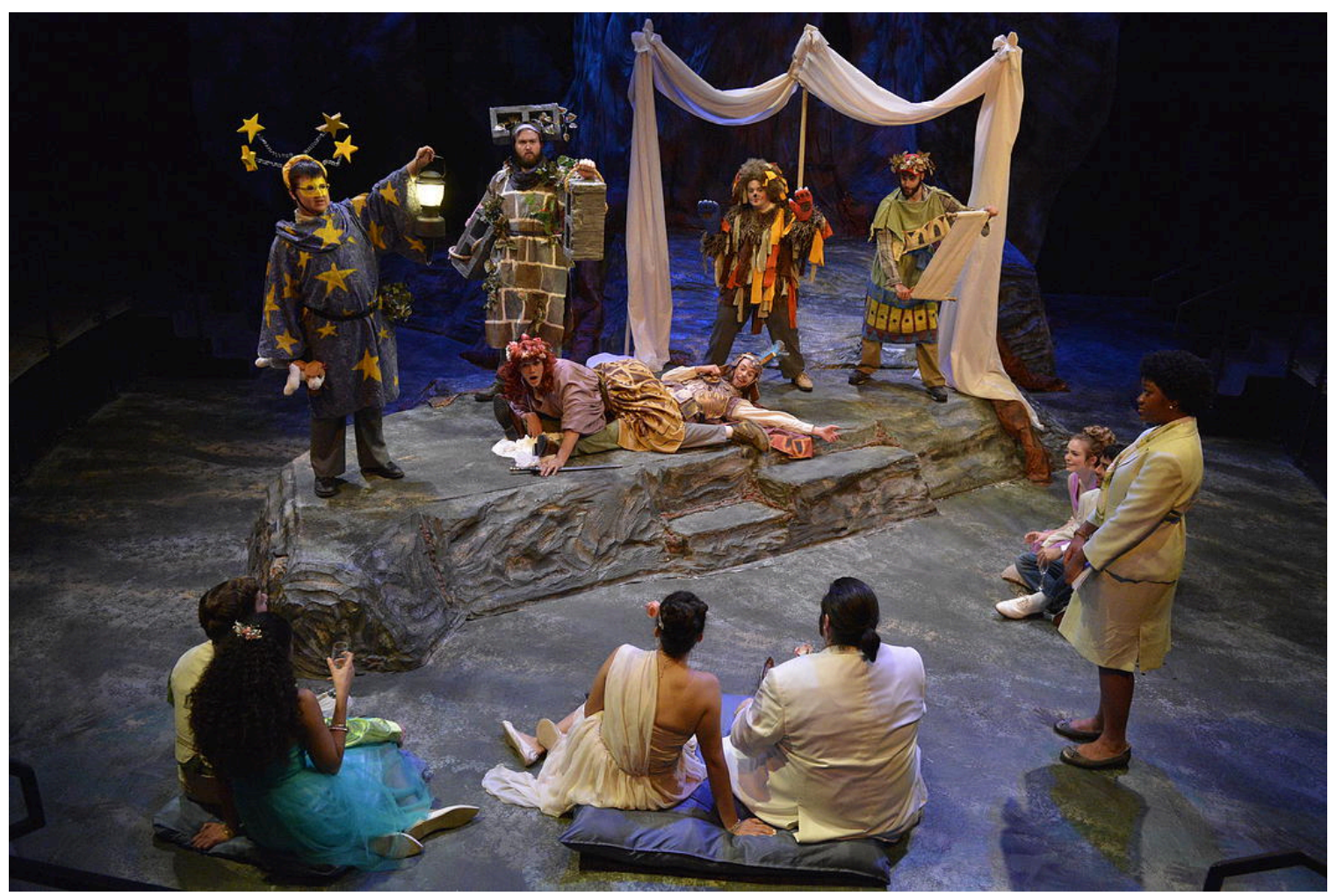

(Act V.I of $A$ Midsummer Night's Dream, "The play within a play")

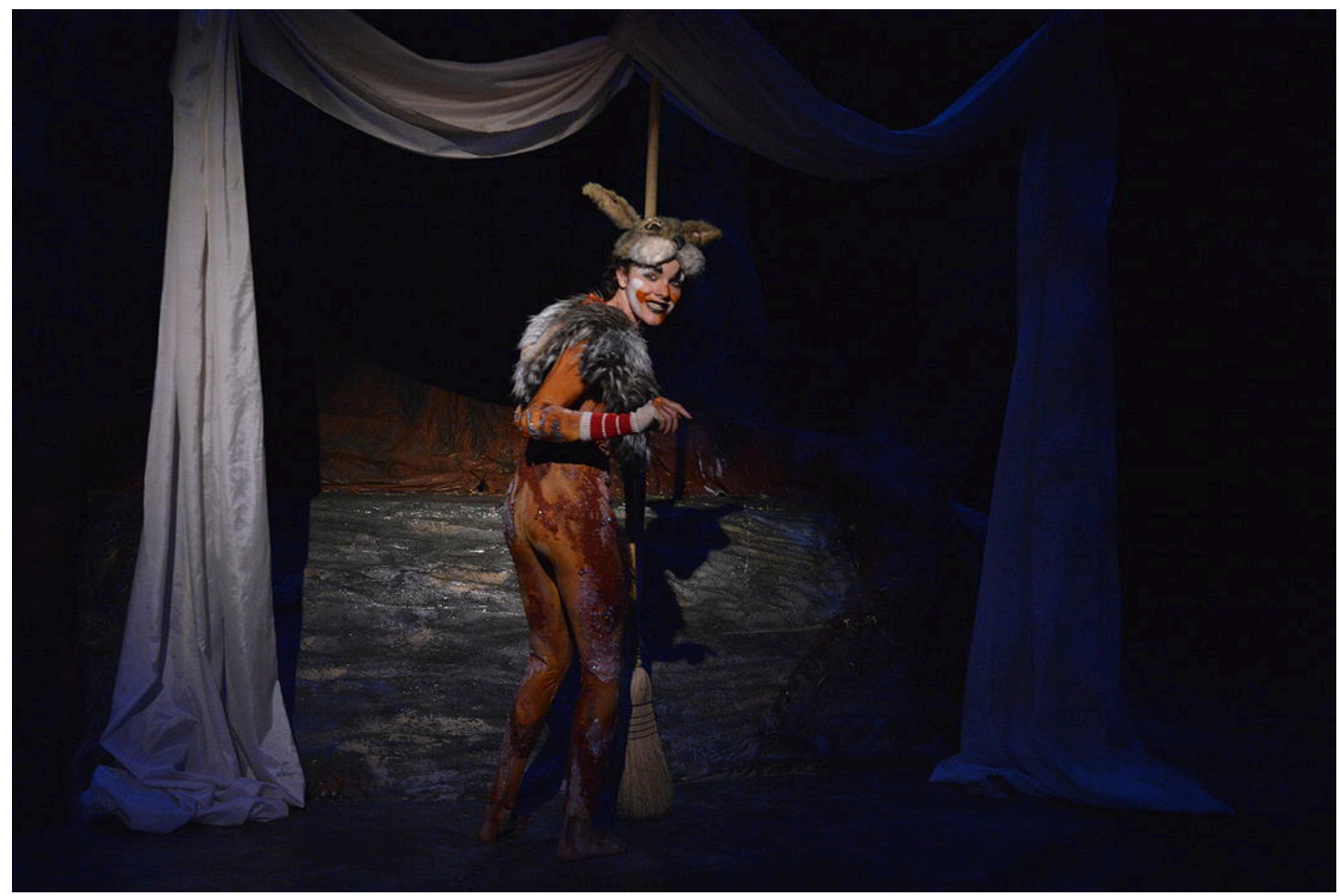

(Act V.I of A Midsummer Night's Dream, "Puck's final moment") 